\title{
Physiological and Biochemical Responses of Soybean to Post Anthesis Drought Stress
}

\author{
Swati Saraswat ${ }^{1}$, Stuti Sharma*, Ajay Meena and R. Shiv Ramakrishna \\ Department of Plant Breeding \& Genetics, Jawaharlal Nehru Krishi Vishwa Vidyalaya, \\ Jabalpur - 482004 (M.P.), India \\ *Corresponding author
}

\section{A B S T R A C T}

\section{Keywords}

Soybean, Post anthesis drought, Drought susceptibility index, CGR, RGR, NAR, RWC

\section{Article Info}

Accepted:

26 April 2020

Available Online:

10 May 2020
The present pot experiment was performed to assess the effect of post anthesis drought stress on physiological and biochemical parameters of soybean and to identify drought tolerant genotypes which can be used further in drought breeding programme. A set of 30 soybean genotypes were evaluated at post anthesis stage under stress and normal condition both to identify the tolerant genotype. Seven physiological parameters namely leaf area index, leaf area duration, crop growth rate, relative growth rate, net assimilation rate, relative water content and soil moisture content by tensiometer and seven biochemical parameter namely membrane stability index, total chlorophyll content, total carotenoid content, lipid peroxidation, proline content, SPAD chlorophyll meter reading (SCMR) and drought susceptibility index were calculated for screening the genotypes. On the basis of yield reduction percentage and drought susceptibility index the identified drought tolerant eight genotypes were JS 20-29, JS 20-98, JS 97-52, JS 21-17, JS 21-73, DAVIS, TGX 852-3D and CAT 2082.

\section{Introduction}

Soybean is an important leguminous crop with high protein and oil contents widely used for human food, animal feed and biofuel production. Although, share of India in the world soybean area is 10 per cent, but its contribution is just only 4 per cent of the total world's production indicating its relatively low productivity as compared to world average (Bhatia et al., 2014). The golden bean is grown mostly by the marginal farmers under rainfed conditions in Madhya Pradesh.

Being a rainfed crop, erratic monsoon, climatic changes and varied eco-edaphic conditions are the major constraints that limit it's productivity. It has been observed in the 
past that, each year one or the other regions and one or the other stages of crop are suffering from unpredicted drought stress (Manavalan et al., 2009).

The abiotic and biotic stresses have serious influence on soybean production Production and productivity of soybean during 2017-18 was low due to uneven distribution of rainfall and drought conditions at critical stages of crop growth in major soybean growing regions (Director's annual report 2018-19).

Drought stress during vegetative stage affects leaf development which begins to curl or drop leading to reduced plant growth with considerable yield reduction. Soybeans are most susceptible to drought injury during the reproductive stages. Drought stress during early reproductive stages have increased flower and pod abortion in later reproductive stages prolonged drought results in small pods with less, smaller and shriveled seeds than normal ( Boyer, 1983).

Drought at seed fill stage is a major limitation to soybean productivity in countries where crop is mainly grown on seasonal rains. Improved translocation of stem reserves to developing seeds under such a condition could play an important role in improving the productivity of soybean (Bhatia et al., 2014).

However, the frequency of occurrence of drought at terminal phase of soybean (seed filling and, after pod and seed numbers are fixed) due to early cessation of monsoon rains is most common. It is accordingly desirable to identify drought tolerant soybean genotypes able to grow well with limited water supplies.

Drought adaptation is determined using different traits in plants among which traits like chlorophyll content, proline content, relative water content, turgidity, antioxidant enzymatic activities and enzyme catalyzed reactions play a crucial role in determining the level of drought adaptation (Hossain et al., 2015).

The climate change is apparent and is a challenge to soybean production. We need to evolve varieties which can withstand the climatic variability such as delayed monsoon, drought conditions, water logged conditions and high temperature (Director's annual report 2018-19). Therefore the present research work aims for screening of soybean genotypes for post anthesis drought tolerance based on physio-biochemical parameters and yield reduction percentage.

\section{Materials and Methods}

Thirty diverse soybean genotypes (consisting of released varieties, and germplasm both exotic and indigenous) were sown in pots inside glasshouse to screen for drought tolerance. The genotypes were procured from ICAR-IISR (Indian Institute of Soybean Research), Indore and JNKVV released varieties from Department of Plant Breeding and Genetics, JNKVV, Jabalpur.

Sowing was done in earthen pots filled with clay loam soil and farmyard manure (FYM) in 3:1 ratio. All recommended agronomic practices were followed to raise the healthy crop plants. The experiment was conducted in Completely Randomised Design (CRD) with three replications at Glass House of Botanical Garden, Department of Plant Physiology, Jawaharlal Nehru Krishi Vishwa Vidyalaya, Jabalpur, Madhya Pradesh during Kharif 2018. Weekly weather dta has been presented in table 1.

\section{A total of 180 pots (06 pots for each genotype) were divided into two categories}

Normal (I): 90 Pots were kept outside the glasshouse and no drought treatment was 
imposed Stress (II): 90 Pots were kept inside the glasshouse during the drought treatment by withholding irrigation method a) After flowering b) at pod initiation stage (that is 15 days non irrigated).

\section{Calculation of leaf area index (LAI)}

LAI expresses the ratio of leaf surface (One side only) to the ground area occupied by the plant or a crop stand worked out as per specifications of Gardner et al., (1985).

$\mathrm{LAI}=$ Total leaf area/ ground area

\section{Calculation of leaf area duration (LAD)}

Leaf area duration expresses the magnitude and persistence of leaf area or leafiness during the period of crop growth. LAD was computed as per the formula suggested by (Watson, 1952).

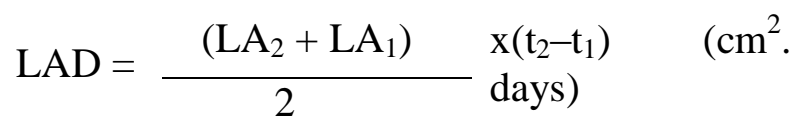

Where, $\mathrm{LA}_{1}$ and $\mathrm{LA}_{2}$ represents the leaf area at two successive time intervals $\left(t_{1}\right.$ and $\left.t_{2}\right)$.

\section{Calculation of crop growth rate (CGR)}

The daily increment in plant biomass is termed as crop growth rate (Watson, 1952). It was determined as per the following formula suggested by (Watson, 1952).

$\underset{=}{\operatorname{CGR}} \frac{\mathrm{W}_{2}-\mathrm{W}_{1}}{\mathrm{p}\left(\mathrm{t}_{2}-\mathrm{t}_{1}\right)}\left(\mathrm{g} \mathrm{cm}^{-2} \mathrm{day}^{-1}\right)$

Where,

$\mathrm{P}=$ ground area $\left(\mathrm{m}^{2}\right)$

$\mathrm{W}_{1}=$ dry weight per unit area at $\mathrm{t}_{1}$

$\mathrm{W}_{2}=$ dry weight per unit area at $\mathrm{t}_{2}$

$\mathrm{t}_{1}=$ days to first sampling

$\mathrm{t}_{2}=$ days to second sampling

\section{Calculation of relative growth rate (RGR)}

The Relative growth rate expresses the dry weight increase in time interval in relation to initial weight. In practical situations, the mean relative growth rate is calculated from measurements at $t_{1}$ and $t_{2}$. It was calculated as per formula given by Watson, (1952).

$$
\mathrm{RGR}=\frac{\mathrm{Ln} \mathrm{W}_{2}-\mathrm{Ln} \mathrm{W}_{1}}{\mathrm{t}_{2}-\mathrm{t}_{1}}\left(\mathrm{~g} \mathrm{~g}^{-1} \mathrm{day}^{-1}\right)
$$

Ln represents natural log.

\section{Calculation of net assimilation rate}

The term, NAR was used by Williams (1946). NAR is defined as dry matter increment per unit leaf area or per unit leaf dry weight per unit of time. The NAR is a measure of the average photosynthetic efficiency of leaves in a crop community.

$\mathrm{NAR}=\frac{\left(\mathrm{W}_{2}-\mathrm{W}_{1}\right)}{\left(\mathrm{t}_{2}-\mathrm{t}_{1}\right)} \times \frac{\left(\log _{\mathrm{e}} \mathrm{L}_{2}-\right.}{\left.\log _{\mathrm{e}} \mathrm{L}_{1}\right)} \quad\left(\mathrm{g} \mathrm{cm}^{-2} \mathrm{day}^{-1}\right)$

Where, W1 and W2 is dry weight of whole plant at time $\mathrm{t} 1$ and $\mathrm{t} 2$ respectively $\mathrm{L} 1$ and $\mathrm{L} 2$ are leaf weights or leaf area at $\mathrm{t} 1$ and $\mathrm{t} 2$ respectively,

$\mathrm{t}_{1}-\mathrm{t}_{2}$ are time interval in days. It was calculated as per the formula given Williams (1946

\section{Calculation of relative water content (RWC)}

To evaluate the plant water status, RWC was measured by Barrs and Weatherley (1962) method. Leaf RWC was estimated by recording the fresh weight $(\mathrm{g})$ of leaf samples, thereafter immediately transferring in petridishes containing distilled water for $4 \mathrm{~h}$ to record turgid weight $(\mathrm{g})$, followed by 
drying in hot air oven at $70^{\circ} \mathrm{C}$ till constant dry weight $(\mathrm{g})$ reached.

RWC $(\%)=[($ Fresh wt. - Dry wt. $) /($ Turgid wt. - Dry wt.)]100

\section{Monitoring of soil moisture content (tensiometric method)}

Soil water potential was measured with help of tensiometer which consist of water field porous ceramic cup in contact with the soil and is connected by water filled tube to a vaccum gauge or mercury manometer and airtight seal on the other end. The body tube connects the porous cup with the vaccum gauge.

The tensiometer is usually filled with water to bring the vaccum gauge reading to zero. When buried in dry soil water tends to flow from the porous cup out to the soil to bring the tensiometer in to hydraulic equilibrium with soil. This creates a vaccum in the body tube that is indicated by vaccum gauge.

\section{Estimation of membrane stability index}

Leaf membrane stability index (MSI) was determined according to the method described by Sairam (1994). Leaf discs $(0.5 \mathrm{~g})$ of uniform diameter were taken in the test tubes containing $10 \mathrm{ml}$ of double distilled water in two sets.

Test tube in one set were kept at $40\left({ }^{\circ} \mathrm{c}\right)$ in a water bath for $30 \mathrm{~min}$ and electrical conductivity of the sample was measured $\left({ }^{0} \mathrm{c}\right)$ using a conductivity meter. Test tubes in the other set were incubated at $100\left({ }^{0} \mathrm{c}\right)$ in the boiling. water bath for $15 \mathrm{~min}$ and their electrical conductivity was measured $\left({ }^{0} \mathrm{c}\right)$. MSI was calculated using the formula given below;

MSI $=\left[1-\left\{\mathrm{C}_{1} / \mathrm{C}_{2}\right\}\right] \times 100$

$\mathrm{C}_{1}=$ electrical conductivity of water containing the leaf sample in set one.

$\mathrm{C}_{2}=$ electrical conductivity of water containing the leaf sample in set two.

\section{Estimation of lipid peroxidation}

Lipid peroxidation was estimated as the thiobarbituric acid reactive substances, according to the method of Heath and Packer (1968). Leaf samples $(0.5 \mathrm{~g})$ were homogenized in $10 \mathrm{ml} 0.1 \%$ trichloro-acetic acid (TCA). The homogenate was centrifuged at $15,000 \mathrm{~g}$ for $15 \mathrm{~min}$. To $1.0 \mathrm{ml}$ aliquot of the supernatant $4.0 \mathrm{ml}$ of $0.5 \%$ thiobarbituric acid (TBA) in 20\% TCA was added (Fig. 16).

The mixture was heated at $95^{\circ} \mathrm{C}$ for $30 \mathrm{~min}$ in the water bath and then cooled under room temperature. After centrifugation at $10,000 \mathrm{~g}$ for $10 \mathrm{~min}$ the absorbance of the supernatant was recorded at $532 \mathrm{~nm}$. The TBARS content was calculated according to its extinction coefficient, i.e., $155 \mathrm{mM}^{-1} \mathrm{~cm}^{-1}$. The values for non-specific absorbance at $600 \mathrm{~nm}$ were subtracted.

\section{Estimation of proline}

Proline content was estimated by method given by Bates et al., (1973).Leaf samples $(0.5 \mathrm{~g})$ were homogenized in $10 \mathrm{ml} 3 \%$ sulphosalicylic acid and were filtered through whatman filter paper. Two $\mathrm{ml}$ of this filtrate was mixed with $2 \mathrm{ml}$ of acid ninhydrin and 2 $\mathrm{ml}$ of glacial acetic acid in a test tube (Fig. 17).

The mixture was heated at $100{ }^{\circ} \mathrm{C}$ in a water bath for 1 hour. The reaction was stopped by removing the tubes from hot water bath and placing them in ice bath. Toluene $(4 \mathrm{ml})$ was added to the mixture and vortexed for 15-20 seconds. The chromophore was aspirated from the aqueous phase. Then the absorbance of toluene phase was measured at $520 \mathrm{~nm}$. 


\section{Estimation of total chlorophyll}

Prepare $80 \%$ acetone. Weight $250 \mathrm{mg}$ of fresh leaf material. Ground the pieces of plant material in pestle and mortar using $5 \mathrm{ml}$ of $80 \%$ acetone. Filter the homogenate in $25 \mathrm{ml}$ volumetric flask by using whatman paper grade one.

Wash out the homogenate 3-4 time with $5 \mathrm{ml}$ of $80 \%$ acetone each time. Make the final volume of filtrate to $25 \mathrm{ml}$ record the absorbance of filtrate at two wavelengths (663 and 645) using spectrophotometer by keeping $80 \%$ acetone as blank (Fig. 18).

The amount of chlorophyll 'a','b' and total are determined using the following formulas given by Arnon, (1949) based on the work of Mac kinney, (1941) who provided the values of extraction coefficients.

Chlorophyll ' $\mathrm{a}$ '

$=\left[\left(12.7 \mathrm{X} \mathrm{A}_{663}\right)-\left(2.69 \mathrm{X} \mathrm{A}_{645}\right)\right] \mathrm{X} \mathrm{V/1000}$ $\mathrm{XW}\left(\mathrm{mg} \mathrm{g}^{-1} \mathrm{fw}\right)$

Chlorophyll ' $\mathrm{b}$ '

$=\left[\left(22.9 \mathrm{X} \mathrm{A}_{645}\right)-\left(4.68 \mathrm{X} \mathrm{A}_{663}\right)\right] \mathrm{X}$ V/ 1000X W ( $\left.\mathrm{mg} \mathrm{g}^{-1} \mathrm{fw}\right)$

Total chlorophyll $(\mathrm{a}+\mathrm{b})=\left[\left(20.2 \times \mathrm{A}_{645}\right)+(8.02\right.$ $\left.\mathrm{X} \mathrm{A}_{663}\right)$ ] X V/1000X W (mg g $\left.{ }^{-1} \mathrm{fw}\right)$

Where,

$\mathrm{A}_{663}=$ Absorbance values at $663 \mathrm{~nm}$

$\mathrm{A}_{645}=$ Absorbance values at $645 \mathrm{~nm}$

$\mathrm{A}_{480}=$ Absorbance values at $480 \mathrm{~nm}$

$\mathrm{W}=$ Weight of the sample in $\mathrm{mg}$

$\mathrm{V}=$ Volume of the solvent used $(\mathrm{ml})$

\section{Estimation of total carotenoid}

The above extract can also be used for the quantification of carotenoids. The absorbance of the carotenoide at $480 \mathrm{~nm}$ is determined using the equations provided by Krik and Allen, (1965). This equation compensates for interference at this wavelength from chlorophyll. Carotenode was estimated with help of following formulae.

T. carotenoids cont.

$$
\underset{\left.\left(0.638 \times \mathrm{A}_{645}\right)\right] \mathrm{V} / 1000 \times \mathrm{W}}{\left[\left(\mathrm{mg} \mathrm{g}^{-1} \mathrm{fW}\right)\right.}-
$$

\section{Estimation of SPAD chlorophyll meter reading (SCMR)}

Soil and plant analysis development (SPAD) values were measured in the middle part of flag leaves using portable Minolta SPAD-502 chlorophyll meter (Minolta camera Co. Ltd., Osaka, Japan) from control plants (normal irrigation) and after 11 days of water deficit stress condition plants. The average readings of 10 leaves per pot was recorded and used in analysis.

\section{Estimation of drought susceptibility index}

The drought susceptibility index was calculated using the formulae given by (Fischer and Maurer, 1978)

$\mathrm{S}=(1-\mathrm{Y} / \mathrm{Yp}) / \mathrm{D}$

Where,

$\mathrm{Y}$ is yield under stress, $\mathrm{Yp}$ is yield without stress and $\mathrm{X}$ and $\mathrm{Xp}$ represent average yield over all varieties under stress and non-stress condition, respectively.

Stress intensity $(D)=(1-X / X p)$

$\mathrm{X}$ is mean $\mathrm{Y}$ of all germplasm; $\mathrm{Xp}$ is mean Yp of all germplasm. The $S$ was used to characterize the relative drought stress tolerance of the various species $\mathrm{S} \leq 0.50$ high drought tolerant, $\mathrm{S} \geq 0.50 \leq 1.00$ moderately stress tolerant and $S>1.00$ Susceptible. 


\section{Results and Discussion}

\section{Effect on physiological growth parameters}

\section{LAI}

LAI of 3-5 is usually necessary for maximum dry matter production of most of the crops (Gardner et al., 1985). In the present study all the high yielding and drought tolerant genotypes recorded higher leaf area index as compared to drought susceptible genotypes (Eck et al., 1987) Soybean genotype TGX 852-3D exhibited highest LAI i.e. 4.38 and 6.37 under stress and normal condition respectively whereas SKY/AK-403 exhibited lowest value of LAI i.e. 1.37 and 3.25 under stress and normal condition respectively (Table no. 2, fig. no. 1). Similar findings were reported by Wang et al., (1995).

\section{LAD}

The LAD of drought tolerant genotypes is higher than drought susceptible genotypes, which is similar to the findings of Mottaghian et al., 2010. Genotype TGX 852-3D exhibited highest leaf area duration i.e $33069.05 \mathrm{~cm}^{2}$ days and $33529.14 \mathrm{~cm}^{2}$ days under normal and stress condition respectively whereas SKY/AK-403 exhibited lowest value of leaf area duration i.e $15482.25 \mathrm{~cm}^{2}$ days and $20885.75 \mathrm{~cm}^{2}$ days under stress and normal condition respectively (Table no.2, fig. no.2). Pandey et al., (1984) have reported similar results.

\section{CGR}

CGR of susceptible genotypes has decreased more than that of the tolerant genotypes. CAT 2082 recorded highest crop growth rate i.e $0.00191 \mathrm{~g} \mathrm{plant}^{-1}$ and $0.00315 \mathrm{~g} \mathrm{plant}^{-1}$ under stress and normal condition respectively while SKY/AK-403 exhibited lowest value of crop growth rate i.e $0.00084 \mathrm{~g} \mathrm{plant}^{-1}$ and 0.00279 g plant ${ }^{-1}$ under stress and normal condition respectively (Table no.2, fig. no. 3). Similar findings have been reported by Wang et al., (1995).

\section{RGR}

Drought sress has led to reduction in RGR. Genotype CAT 2082 has recorded highest value of RGR i.e 0.0305 g.day $^{-1}$ and 0.0422 g.day $^{-1}$ respectively while genotype AMS MB-518 recorded lowest value of RGR i.e 0.0185 g.day $^{-1}$ and 0.0373 g.day $^{-1}$ under stress and normal condition respectively (Table no. 3, fig. no. 4). Similar findings have been reported by Wang et al., (1995).

\section{NAR}

DAVIS has recorded highest NAR i.e $0.000257 \mathrm{mg} . \mathrm{m}^{-2} \cdot \mathrm{day}^{-1}$ and $0.000298 \mathrm{mg} . \mathrm{m}^{-}$ ${ }^{2}$.day $^{-1}$ under stress and normal condition respectively. AMS $19 \mathrm{~B}$ has recorded lowest NAR $0.000102 \mathrm{mg} \cdot \mathrm{m}^{-2} \cdot \mathrm{day}^{-1}$ and 0.000155 $\mathrm{mg} . \mathrm{m}^{-2} \cdot$ day $^{-1}$ under stress and normal condition respectively (Table no. 3 , fig no. 5).

\section{RWC}

Drought stress causes water loss within the plant and result in relative water content (RWC) reduction, this parameter is one of the most reliable and widely used indicator for defining both the sensitivity and the tolerance to water deficit in plants (Rampino et al., 2012). In the present investigation, RWC consistently decreased under drought in comparison to well watered conditions in all the genotypes (Lobato et al., 2008). RWC decreased significantly when drought conditions were created (Chowdhury et al., 2017). JS 20-29 recorded highest RWC 90.54 $\%$ and $69.74 \%$ under normal and stress condition respectively while genotype AMS 59 recorded lowest value of RWC i.e. 82.00 $\%$ and $59.14 \%$ under normal and stress 
condition respectively (Table no. 3 , fig. no. 6 ). It has been suggested that the plants to retain a high RWC during stress period are conspired as tolerant once (Barr and Weatherley, 1962).

\section{Soil moisture content (tensiometric method)}

The tensiometeric reading (Fig. 15) at the beginning was zero and at $15^{\text {th }}$ day of drought imposement it reached -55.1 Kpa after which lifesaving irrigation was given to the plants under stress condition (fig no. 7 and 15)

\section{Effect on biochemical parameters}

\section{MSI}

Membrane stability index (MSI) measured from electrolytic leakage from affected leaf tissue is commonly used to measure the stress induced damage to the cells and used as a screen for abiotic stress tolerance. (Bajji et al., 2002). MSI has frequently been used for screening against drought in various crops (Golezani et al., 2013).It got decreased under post anthesis drought stress (Table no.4, fig. no. 8). JS 97-52 recorded highest membrane stability index i.e. $81.35 \%$ and $72.75 \%$ under normal and stress condition respectively while AMS 19 B recorded lowest value i.e. $68.65 \%$ and $54.78 \% \%$ under normal and stress condition respectively (Chowdhury et al., 2017). The dysfunction of membranes is expressed as increased permeability and leakage of ions, the efflux of electrolytes is used to calculate this Index.

\section{Lipid peroxidation}

Lipid peroxidation is oxidative degradation of lipid-fatty acids by reactive oxygen species. The level of lipid peroxidation is measured in terms of thiobarbituric acid reactive substances (TBARS) content (Heath and
Packer, 1969). All the genotypes exhibited higher MDA content in leaves under stress condition as compared to normal condition. Guler and Pehlivan (2016) suggested that drought stress enhances lipid peroxidation.

Genotype AMS 59 recorded highest lipid peroxidation value (603.35) under stress condition as compared to 420.19 value under normal condition (Table no.4, fig. no 9 and 16).

\section{Proline content}

Proline a compatible solute and an amino acid, is involved in osmotic adjustment (OA) and protection of cells during dehydration (Zhang et al., 2009). Proline can scavenge free radicals and reduce damage due to free radicles during drought stress. Growing body of evidence indicated that proline content increases during drought stress and proline accumulation is associated with improvement in drought tolerance in plants (Seki et al., 2007; Zhang et al., 2009).

Highest increase (4 folds) was recorded by genotype JS 97-52 i.e. $24.02 \mu$ moles per gram tissue and $100.84 \mu$ moles per gram tissue under normal and stress condition respectively (Table no.4, fig.no.10 and 17). Whereas lowest proline content was recorded by genotype JS 20-69 i.e. $6.56 \mu$ moles per gram tissue and $12.39 \mu$ moles per gram tissue.

Enhancing trends of proline content during the present investigation indicated that proline accumulation has the linearity to osmotic stress. Elevated proline content under drought stress maintains plant existence and cell water level (Ghorbanli et al., 2012). Proline accumulates in higher concentration in response to different abiotic environmental stresses specially drought stress (KaviKishore et al., 2005). 


\section{Total chlorophyll content}

During present investigation, all the genotypes have shown reduction in chlorophyll content in stress conditions when compared to normal condition. Souza et al., (1997) reported that the moisture stress accelerated leaf senescence, as shown by more rapid decline in leaf chlorophyll content and shortened the seed filling period of soybean. Highest chlorophyll content was recorded by the genotype JS 97-52 mg. ${ }^{-1}$ DW i.e. 8.48 and $6.07 \mathrm{mg} . \mathrm{g}^{-1}$ DW under normal and stress condition respectively (Table no.5, fig. no.11 and 18).

Whereas genotype JS 20-69 recorded lowest chlorophyll content i.e. $3.12 \mathrm{mg}^{-1}{ }^{-1} \mathrm{DW}$ and $2.04 \mathrm{mg} . \mathrm{g}^{-1} \mathrm{DW}$ under normal and stress condition respectively. Hossain et al., (2014) reported that total chlorophyll content of leaves of soybean genotypes was lower under the drought stress than that of well-watered plants under sequential water restriction. Park et al., (1998) stated that leaf chlorophyll content in soybean was highest at flowering and decreased by water stress.

\section{Total carotenoid content}

Carotenoids are $\mathrm{C}_{40}$ isoprenoids that are located in the plastids of both photosynthetic and non-photosynthetic plant tissues. In our present study, due to post anthesis drought stress for 15 days, carotenoid content got reduced by $33 \%$ over normal condition. Similar results were also reported by Farooq et al., (2009) that drought stress caused a large decline in carotenoid contents in wheat due to imposed water deficit stress condition. The Reduction in carotenoid content shows positive correlation with drought susceptibility genotype DAVIS recorded highest carotenoid content i.e. $0.47 \mathrm{mg} \mathrm{g}^{-1}$ DW which shows positive association of carotenoid content with seed yield under drought condition which is in consistent with Rahbarian et al., (2001) who reported maximum carotenoid content in drought tolerant genotypes of chickpea under water deficit stress condition and $0.40 \mathrm{mg} \mathrm{g}^{-1} \mathrm{DW}$ under normal and stress condition respectively whereas genotype JS 21-72 recorded lowest carotenoid content i.e. 0.04 $\mathrm{mg} \mathrm{g}^{-1} \mathrm{DW}$ and $0.01 \mathrm{mg} \mathrm{g}^{-1}$ DW under normal and stress condition respectively( Table no. 5, fig.no. 12 and 18).

\section{SCMR}

The SPAD (Soil Plant Analysis Development) chlorophyll meter is a simple, rapid, and nondestructive method for evaluation of chlorophyll contents in leaves. chlorophyll content index has positive association with drought tolerance trait, which goes similar with the findings of (Khalegi et al., 2012; Li et al., 2012). Genotype TGX 852-3D recorded highest value i.e. 56.44 and 50.00 under normal and stress condition respectively. Whereas genotype SKY/AK-403 recorded lowest value i.e. 31.24 and 26.05 under normal and stress condition respectively (Table no.5, fig. no. 13) which also support our hypothesis, that drought tolerant genotypes have the potential to retain maximum chlorophyll content as compared to drought susceptible genotypes under imposed water deficit stress condition at post pod initiation stage.

\section{DSI}

Drought susceptibility index was used to characterize the relative drought stress $(\mathrm{S} \leq$ 0.50 as high drought tolerant; $\mathrm{S} \geq 0.5 \leq 1.00$ as moderately stress tolerant; $\mathrm{S}>1.00$ as susceptible genotypes) (Fischer and Maurer, 1978). In our present study, we used DSI of yield as a parameters to identify drought tolerant genotypes, which is in conformity with (Mall et al., 2011; Babu et al., 2011). 
Table.A

\begin{tabular}{|c|c|l|}
\hline S.No & Genotype & \multicolumn{1}{|c|}{ Attribute } \\
\hline $\mathbf{1 .}$ & JS 20-29 & Highest relative water content \\
\hline $\mathbf{2 .}$ & JS 20-98 & $\begin{array}{l}\text { Highest membrane stability index, highest chlorophyll, } \\
\text { highest } \begin{array}{l}\text { proline lowest drought } \\
\text { susceptibility index }\end{array}\end{array}$ \\
\hline $\mathbf{3 .}$ & JS $97-52$ & \\
\hline $\mathbf{4 .}$ & JS $21-17$ & Highest net assimilation rate, highest carotenoid content \\
\hline $\mathbf{5 .}$ & JS 21-73 & $\begin{array}{l}\text { Highest leaf area index, highest leaf area duration, highest } \\
\text { SPAD value }\end{array}$ \\
\hline $\mathbf{7 .}$ & TGX $852-3 \mathrm{D}$ & Highest crop growth rate, highest relative growth rate \\
\hline $\mathbf{8 .}$ & CAT 2082 & \\
\hline
\end{tabular}

Table.1 Weekly weather data during the experimental period Kharif season (June to October 2018) Bold data shows the period of withholding irrigation i.e. drought stress period

\begin{tabular}{|c|c|c|c|c|c|c|c|c|c|}
\hline Month & $\begin{array}{l}\text { Stan } \\
\text { dard } \\
\text { week }\end{array}$ & $\begin{array}{c}\text { Tem } \\
\text { Max. } \\
\left({ }^{0} \mathbf{c}\right)\end{array}$ & $\begin{array}{l}\text { Tem } \\
\text { min. } \\
\left({ }^{0} \mathrm{C}\right)\end{array}$ & $\begin{array}{l}\text { Sun } \\
\text { Shine } \\
\text { hrs. }\end{array}$ & $\begin{array}{c}\text { Rainfall } \\
\text { (mm) }\end{array}$ & $\begin{array}{c}\text { RH } \\
(\%) \\
\text { Mor. }\end{array}$ & $\begin{array}{l}\text { RH } \\
(\%) \\
\text { Eve. }\end{array}$ & $\begin{array}{l}\text { Wind } \\
\text { Speed } \\
\text { Km/hr }\end{array}$ & $\begin{array}{c}\text { Rainy } \\
\text { days }\end{array}$ \\
\hline \multirow[t]{4}{*}{ Jun. } & 23 & 39.6 & 27.4 & 4.9 & 14.4 & 67.4 & 47.1 & 6.8 & 1 \\
\hline & 24 & 31.9 & 24.8 & 1.9 & 6.6 & 94 & 79.6 & 4.7 & 1 \\
\hline & 25 & 29.9 & 24.5 & 0.4 & 16 & 96.1 & 86 & 7.8 & 2 \\
\hline & 26 & 33.6 & 25.3 & 2.2 & 29.9 & 84.6 & 76.3 & 5.6 & 3 \\
\hline \multirow[t]{4}{*}{ Jul. } & 27 & 32.5 & 24.6 & 3.9 & 44.1 & 86 & 67.4 & 7.2 & 3 \\
\hline & 28 & 32.4 & 24.8 & 1.8 & 64.6 & 92.4 & 78.1 & 5.2 & 6 \\
\hline & 29 & 31.4 & 24.8 & 1.8 & 137 & 95.3 & 79.9 & 6.7 & 2 \\
\hline & 30 & 28.7 & 23.6 & 0 & 106.9 & 95 & 88.4 & 7.9 & 4 \\
\hline \multirow[t]{5}{*}{ Aug. } & 31 & 29.6 & 24.3 & 0.5 & 2.8 & 89 & 72.9 & 7.3 & 0 \\
\hline & 32 & 29.4 & 24.3 & 0.6 & 187.9 & 93.3 & 83.7 & 6.2 & 4 \\
\hline & 33 & 30.3 & 24.6 & 2.6 & 86.3 & 94 & 77.9 & 5.4 & 6 \\
\hline & 34 & 28.5 & 23.3 & 0.9 & 138.8 & 95.1 & 93 & 6.2 & 5 \\
\hline & 35 & 26.8 & 23.4 & 0.3 & 193.8 & 95.3 & 91.4 & 6.2 & 5 \\
\hline \multirow[t]{4}{*}{ Sep. } & 36 & 26.8 & 22.6 & 0.3 & 72.2 & 96.4 & 84.3 & 6.4 & 4 \\
\hline & 37 & 31.2 & 22.7 & 8.1 & 0 & 90 & 69.1 & 4.4 & 0 \\
\hline & 38 & 31.1 & 22.7 & 6 & 11.8 & 91 & 72 & 5.8 & 1 \\
\hline & 39 & 32.8 & 22.1 & 8 & 0 & 90 & 61.7 & 3.5 & 0 \\
\hline \multirow[t]{4}{*}{ Oct. } & 40 & 34.2 & 19.8 & 9.2 & 0 & 88.7 & 53.9 & 2.8 & 0 \\
\hline & 41 & 32 & 18 & 8.1 & 0 & 86.4 & 60.7 & 3.6 & 0 \\
\hline & 42 & 32.7 & 17.8 & 8.7 & 0 & 85.7 & 53.3 & 2.6 & 0 \\
\hline & 43 & 31.9 & 14.7 & 9.2 & 0 & 84.9 & 52.9 & 2.7 & 0 \\
\hline
\end{tabular}


Table.2 Leaf area index, Leaf area duration and crop growth rate of 30 soybean genotypes under normal and stress condition

\begin{tabular}{|c|c|c|c|c|c|c|}
\hline \multirow[t]{2}{*}{ GENOTYPES } & \multicolumn{2}{|c|}{$\begin{array}{l}\text { LEAF AREA } \\
\text { INDEX }\end{array}$} & \multicolumn{2}{|c|}{$\begin{array}{l}\text { LEAF AREA } \\
\text { DURATION }\end{array}$} & \multicolumn{2}{|c|}{$\begin{array}{l}\text { CROP GROWTH } \\
\text { RATE }\end{array}$} \\
\hline & Normal & Stress & Normal & Stress & Normal & Stress \\
\hline JS 20-29 & 4.64 & 2.68 & 28513.10 & 23568.10 & 0.00312 & 0.00162 \\
\hline JS 20-69 & 4.23 & 2.27 & 25721.15 & 20726.50 & 0.00310 & 0.00112 \\
\hline JS 20-98 & 3.97 & 1.99 & 24457.70 & 19469.25 & 0.00300 & 0.00187 \\
\hline JS 97-52 & 4.19 & 2.20 & 24948.25 & 20892.73 & 0.00299 & 0.00178 \\
\hline DAVIS & 4.17 & 2.18 & 25267.40 & 21305.54 & 0.00304 & 0.00164 \\
\hline YOUNG & 3.89 & 1.93 & 24162.10 & 18145.55 & 0.00303 & 0.00103 \\
\hline JS 21-17 & 5.67 & 3.69 & 34224.25 & 31275.75 & 0.00310 & 0.00172 \\
\hline AMS MB -518 & 5.14 & 3.18 & 30425.40 & 25425.40 & 0.00296 & 0.00115 \\
\hline TGX 852 3D & 6.37 & 4.38 & 38069.05 & 33529.14 & 0.00307 & 0.00180 \\
\hline MACS-58 & 4.95 & 2.99 & 29400.70 & 25428.57 & 0.00304 & 0.00136 \\
\hline SKY/AK-403 & 3.25 & 1.37 & 20885.75 & 15482.25 & 0.00279 & 0.00084 \\
\hline HARDEE & 3.74 & 1.81 & 22965.10 & 16879.47 & 0.00302 & 0.00105 \\
\hline JS 21-73 & 5.21 & 3.29 & 31523.05 & 27645.75 & 0.00305 & 0.00179 \\
\hline CAT-142 & 4.83 & 2.87 & 29006.75 & 25420.26 & 0.00307 & 0.00104 \\
\hline CAT-649 & 3.91 & 1.91 & 23695.60 & 18695.27 & 0.00303 & 0.00148 \\
\hline CAT -703 & 3.40 & 1.45 & 20889.75 & 19757.16 & 0.00296 & 0.00139 \\
\hline CAT-3293 & 3.96 & 1.98 & 24790.70 & 18985.75 & 0.00301 & 0.00127 \\
\hline CAT-2082 & 4.52 & 2.55 & 27768.55 & 24543.46 & 0.00315 & 0.00191 \\
\hline AGS-38 & 4.32 & 2.37 & 26534.45 & 20963.16 & 0.00293 & 0.00129 \\
\hline AMS-59 & 3.71 & 1.78 & 23089.85 & 18523.72 & 0.00294 & 0.00123 \\
\hline AMS-19B & 3.95 & 1.96 & 23970.60 & 17896.21 & 0.00291 & 0.00145 \\
\hline AMS-26A & 4.66 & 2.68 & 27649.75 & 23521.42 & 0.00304 & 0.00141 \\
\hline AMS-148 & 4.08 & 2.09 & 24100.80 & 19236.72 & 0.00309 & 0.00117 \\
\hline SQL-8 & 4.06 & 2.12 & 25600.90 & 21247.23 & 0.00305 & 0.00110 \\
\hline SQL-31 & 4.13 & 2.17 & 25308.35 & 21438.76 & 0.00302 & 0.00134 \\
\hline SQL-88 & 4.75 & 2.72 & 28377.30 & 22652.15 & 0.00298 & 0.00162 \\
\hline SQL-89 & 4.69 & 2.65 & 29311.15 & 25234.18 & 0.00304 & 0.00152 \\
\hline SQL-106 & 3.61 & 1.64 & 21587.45 & 17854.34 & 0.00301 & 0.00147 \\
\hline JS 21-71 & 4.43 & 2.45 & 27430.80 & 23675.17 & 0.00299 & 0.00162 \\
\hline JS 21-72 & 3.89 & 1.87 & 23048.20 & 18985.27 & 0.00298 & 0.00119 \\
\hline
\end{tabular}


Table.3 Relative growth rate, Net assimilation rate and Relative water content of 30 soybean genotypes under both normal and stress condition

\begin{tabular}{|c|c|c|c|c|c|c|}
\hline \multirow[t]{2}{*}{ Genotypes } & \multicolumn{2}{|c|}{$\begin{array}{c}\text { Relative Growth } \\
\text { Rate }\end{array}$} & \multicolumn{2}{|c|}{ Net Assimilation Rate } & \multicolumn{2}{|c|}{ Relative water content } \\
\hline & Normal & Stress & Normal & Stress & Normal & Stress \\
\hline JS 20-29 & 0.0393 & 0.0271 & 0.000274 & 0.000238 & 90.54 & 69.74 \\
\hline JS 20-69 & 0.0470 & 0.0251 & 0.000204 & 0.000145 & 86.74 & 61.51 \\
\hline JS 20-98 & 0.0399 & 0.0297 & 0.000293 & 0.000265 & 87.33 & 66.94 \\
\hline JS 97-52 & 0.0422 & 0.0265 & 0.000294 & 0.000273 & 88.69 & 68.65 \\
\hline DAVIS & 0.0416 & 0.0287 & 0.000298 & 0.000257 & 85.33 & 69.66 \\
\hline YOUNG & 0.0446 & 0.0259 & 0.000200 & 0.000141 & 89.35 & 68.21 \\
\hline JS 21-17 & 0.0390 & 0.0261 & 0.000254 & 0.000232 & 88.80 & 69.18 \\
\hline AMS MB-518 & 0.0373 & 0.0185 & 0.000155 & 0.000102 & 83.30 & 62.18 \\
\hline TGX 852 3D & 0.0376 & 0.0245 & 0.000283 & 0.000259 & 89.00 & 68.75 \\
\hline MACS-58 & 0.0403 & 0.0259 & 0.000173 & 0.000129 & 85.43 & 62.91 \\
\hline SKY/AK-403 & 0.0422 & 0.0237 & 0.000248 & 0.000156 & 82.75 & 61.35 \\
\hline HARDEE & 0.0411 & 0.0217 & 0.000211 & 0.000159 & 90.54 & 60.38 \\
\hline JS 21-73 & 0.0396 & 0.0291 & 0.000259 & 0.000238 & 86.74 & 70.31 \\
\hline CAT-142 & 0.0421 & 0.0239 & 0.000179 & 0.000134 & 87.33 & 63.69 \\
\hline CAT-649 & 0.0397 & 0.0189 & 0.000208 & 0.000162 & 88.69 & 68.47 \\
\hline CAT-703 & 0.0431 & 0.0236 & 0.000217 & 0.000171 & 85.33 & 63.77 \\
\hline CAT-3293 & 0.0388 & 0.0127 & 0.000191 & 0.000159 & 89.35 & 60.52 \\
\hline CAT-2082 & 0.0422 & 0.0305 & 0.000272 & 0.000255 & 88.80 & 68.21 \\
\hline AGS-38 & 0.0397 & 0.0199 & 0.000166 & 0.000113 & 83.30 & 66.69 \\
\hline AMS-59 & 0.0425 & 0.0245 & 0.000191 & 0.000148 & 82.00 & 59.14 \\
\hline AMS-19B & 0.0418 & 0.0232 & 0.000136 & 0.000105 & 85.43 & 61.45 \\
\hline AMS-26A & 0.0455 & 0.0293 & 0.000184 & 0.000143 & 90.54 & 65.55 \\
\hline AMS-149 & 0.0486 & 0.0279 & 0.000223 & 0.000161 & 86.74 & 70.09 \\
\hline SQL-8 & 0.0422 & 0.0241 & 0.000203 & 0.000149 & 87.33 & 63.40 \\
\hline SQL-31 & 0.0397 & 0.0201 & 0.000192 & 0.000154 & 88.69 & 61.51 \\
\hline SQL-88 & 0.0411 & 0.0235 & 0.000168 & 0.000117 & 85.33 & 64.32 \\
\hline SQL-89 & 0.0409 & 0.0279 & 0.000176 & 0.000129 & 89.35 & 65.92 \\
\hline SQL-106 & 0.0468 & 0.0287 & 0.000228 & 0.000185 & 88.80 & 58.27 \\
\hline JS 21-71 & 0.0427 & 0.0275 & 0.000170 & 0.000138 & 83.30 & 63.36 \\
\hline JS 21-72 & 0.0403 & 0.0219 & 0.000210 & 0.000157 & 89.00 & 65.67 \\
\hline
\end{tabular}


Table.4 Membrane stability index, lipid peroxidation and proline content of 30 soybean genotypes under both normal and stress condition

\begin{tabular}{|c|c|c|c|c|c|c|}
\hline \multirow[t]{2}{*}{ Genotypes } & \multicolumn{2}{|c|}{$\begin{array}{c}\text { Membrane Stability } \\
\text { Index (\%) }\end{array}$} & \multicolumn{2}{|c|}{$\begin{array}{c}\text { Lipid Peroxidation } \\
(\mathrm{nmol} \text { TBARS g } \\
\text { DW) }\end{array}$} & \multicolumn{2}{|c|}{ Proline Content } \\
\hline & Normal & Stress & Normal & Stress & Normal & Stress \\
\hline JS 20-29 & 81.04 & 67.61 & 178.65 & 326.97 & 26.32 & 78.96 \\
\hline JS 20-69 & 80.56 & 65.04 & 153.48 & 308.90 & 6.56 & 12.39 \\
\hline JS 20-98 & 77.15 & 66.70 & 155.68 & 250.45 & 30.45 & 121.8 \\
\hline JS 97-52 & 81.35 & 72.75 & 145.94 & 283.61 & 24.02 & 100.84 \\
\hline DAVIS & 78.29 & 67.81 & 144.58 & 169.81 & 29.23 & 102.62 \\
\hline YOUNG & 81.03 & 59.02 & 145.94 & 285.23 & 8.132 & 16.654 \\
\hline JS 21-17 & 79.10 & 69.25 & 133.35 & 199.94 & 34.02 & 91.854 \\
\hline AMS MB-518 & 80.28 & 69.72 & 339.68 & 494.65 & 21.363 & 42.72 \\
\hline TGX 852-3D & 81.05 & 70.17 & 234.00 & 390.26 & 19.23 & 76.92 \\
\hline MACS-58 & 78.62 & 65.44 & 264.19 & 335.19 & 10.98 & 40.23 \\
\hline SKY/AK-403 & 72.15 & 61.14 & 238.24 & 295.13 & 24.54 & 48.45 \\
\hline HARDEE & 82.55 & 67.13 & 208.84 & 292.19 & 12,34 & 29.56 \\
\hline JS 21-73 & 81.34 & 74.41 & 188.71 & 229.45 & 20.02 & 72.072 \\
\hline CAT-142 & 76.85 & 68.85 & 221.42 & 357.68 & 15.92 & 31.45 \\
\hline CAT-649 & 77.44 & 67.38 & 173.61 & 272.77 & 16.02 & 32.088 \\
\hline CAT-703 & 73.14 & 68.27 & 241.55 & 299.77 & 13.45 & 22.871 \\
\hline CAT-3293 & 75.61 & 63.95 & 279.29 & 356.13 & 19.41 & 57.89 \\
\hline CAT-2082 & 75.19 & 64.33 & 319.55 & 420.90 & 22.925 & 67.62 \\
\hline AGS-38 & 77.83 & 66.25 & 264.19 & 387.39 & 11.006 & 33.524 \\
\hline AMS-59 & 68.65 & 54.78 & 420.19 & 603.35 & 15.675 & 30.957 \\
\hline AMS-19B & 70.25 & 54.77 & 317.03 & 514.84 & 27.750 & 57.917 \\
\hline AMS-26A & 78.92 & 66.70 & 231.48 & 478.00 & 19.706 & 39.745 \\
\hline AMS-148 & 79.39 & 61.49 & 334.65 & 456.00 & 17.352 & 31.218 \\
\hline SQL-8 & 75.75 & 61.53 & 407.61 & 515.48 & 8.178 & 24.32 \\
\hline SQL-31 & 81.48 & 61.27 & 327.10 & 489.00 & 9.098 & 21.03 \\
\hline SQL-88 & 73.70 & 59.81 & 347.23 & 482.97 & 12.229 & 25.699 \\
\hline SQL-89 & 76.48 & 59.60 & 246.58 & 391.35 & 22.664 & 33.306 \\
\hline SQL-106 & 75.82 & 64.08 & 281.81 & 332.39 & 15.530 & 39.135 \\
\hline JS 21-71 & 69.82 & 58.85 & 269.23 & 385.87 & 17.966 & 35.438 \\
\hline JS 21-72 & 75.52 & 59.24 & 286.84 & 380.65 & 12.34 & 18.96 \\
\hline
\end{tabular}


Table.5 Total chlorophyll, total Carotenoid, SPAD value and Drought susceptibility index of 30 soybean genotypes under both normal and stress condition

\begin{tabular}{|c|c|c|c|c|c|c|c|}
\hline \multirow[t]{2}{*}{ Genotypes } & \multicolumn{2}{|c|}{$\begin{array}{c}\text { Total Chlorophyll } \\
\text { Content (mg g } \\
\text { DW) }\end{array}$} & \multicolumn{2}{|c|}{$\begin{array}{c}\text { Total Carotenoid } \\
\text { Content (mg g }{ }^{-1} \\
\text { DW) }\end{array}$} & \multicolumn{2}{|c|}{$\begin{array}{l}\text { SPAD Chlorophyll } \\
\text { Meter Reading }\end{array}$} & \multirow[t]{2}{*}{ DSI } \\
\hline & Normal & Stress & Normal & Stress & Normal & Stress & \\
\hline JS 20-29 & 4.43 & 3.19 & 0.18 & 0.12 & 39.50 & 36.00 & 0.25 \\
\hline JS 20-69 & 3.12 & 2.04 & 0.15 & 0.10 & 38.53 & 31.40 & 0.89 \\
\hline JS 20-98 & 7.45 & 5.97 & 0.13 & 0.08 & 40.33 & 38.63 & 0.35 \\
\hline JS 97-52 & 8.48 & 6.07 & 0.32 & 0.27 & 54.67 & 50.23 & 0.18 \\
\hline DAVIS & 6.80 & 5.95 & 0.47 & 0.40 & 40.70 & 38.00 & 0.41 \\
\hline YOUNG & 5.24 & 2.72 & 0.12 & 0.09 & 43.93 & $\mathbf{3 8 . 0 0}$ & 1.98 \\
\hline JS 21-17 & 4.91 & 4.19 & 0.13 & 0.09 & 35.43 & 31.90 & 0.28 \\
\hline $\begin{array}{c}\text { AMS MB- } \\
518\end{array}$ & 6.96 & 5.17 & 0.24 & 0.19 & 42.62 & 36.60 & 1.32 \\
\hline TGX 852-3D & 6.63 & 5.34 & 0.24 & 0.19 & 56.44 & $\mathbf{5 0 . 0 0}$ & 0.26 \\
\hline MACS-58 & 6.96 & 4.50 & 0.21 & 0.15 & 38.27 & 32.20 & 1.12 \\
\hline $\begin{array}{c}\text { SKY/AK- } \\
403\end{array}$ & 4.58 & 3.54 & 0.11 & 0.05 & 31.24 & 26.05 & 1.16 \\
\hline HARDEE & 5.62 & 4.12 & 0.32 & 0.24 & 54.34 & 36.90 & 1.41 \\
\hline JS 21-73 & 6.94 & 5.88 & 0.37 & 0.32 & 55.40 & 49.50 & 0.13 \\
\hline CAT-142 & 4.77 & 3.67 & 0.26 & 0.10 & 51.67 & 30.83 & 0.81 \\
\hline CAT-649 & 6.15 & 2.02 & 0.05 & 0.02 & 38.87 & 30.63 & 0.54 \\
\hline CAT-703 & 3.97 & 2.52 & 0.12 & 0.06 & 33.60 & 27.60 & 0.57 \\
\hline CAT-3293 & 5.87 & 2.91 & 0.21 & 0.12 & 34.47 & 31.67 & 0.55 \\
\hline CAT-2082 & 4.54 & 3.98 & 0.22 & 0.18 & 38.60 & 32.00 & 0.24 \\
\hline AGS-38 & 6.29 & 3.47 & 0.25 & 0.19 & 35.43 & 26.47 & 1.15 \\
\hline AMS-59 & 6.49 & 5.20 & 0.20 & 0.12 & 54.17 & 25.73 & 1.03 \\
\hline AMS-19B & 6.90 & 3.57 & 0.16 & 0.09 & 51.80 & 36.87 & 1.11 \\
\hline AMS-26A & 6.95 & 4.72 & 0.17 & 0.14 & 47.33 & 35.47 & 0.71 \\
\hline AMS-148 & 5.94 & 3.66 & 0.28 & 0.20 & 38.67 & 32.67 & 1.43 \\
\hline SQL-8 & 6.16 & 4.19 & 0.12 & 0.09 & 46.73 & 32.03 & 1.93 \\
\hline SQL-31 & 5.43 & 2.02 & 0.23 & 0.09 & 36.43 & 33.03 & 1.69 \\
\hline SQL-88 & 4.32 & 4.19 & 0.17 & 0.14 & 36.00 & 31.17 & 0.61 \\
\hline SQL-89 & 5.57 & 5.10 & 0.29 & 0.18 & 53.67 & 37.70 & 1.53 \\
\hline SQL-106 & 6.61 & 4.93 & 0.29 & 0.23 & 46.00 & 27.60 & 0.56 \\
\hline JS 21-71 & 5.76 & 3.66 & 0.11 & 0.07 & 51.80 & 30.33 & 0.58 \\
\hline JS 21-72 & 6.27 & 2.07 & 0.04 & 0.01 & 48.17 & 33.40 & 2.00 \\
\hline
\end{tabular}


Table.6 Seed yield, yield reduction percentage and drought susceptibility index of 30 soybean genotypes under both normal and stress condition

\begin{tabular}{|c|c|c|c|c|}
\hline \multirow[t]{2}{*}{ GENOTYPES } & \multicolumn{2}{|c|}{ SEED YIELD (g) } & \multirow{2}{*}{$\begin{array}{l}\text { YIELD } \\
\text { REDUCTION } \\
\text { PERCENTAGE }\end{array}$} & \multirow{2}{*}{$\begin{array}{c}\text { DROUGHT } \\
\text { SUSCEPTIBILITY } \\
\text { INDEX (DSI) }\end{array}$} \\
\hline & NORMAL & STRESS & & \\
\hline JS 20-29 & 5.13 & 4.65 & 9.41 & 0.25 \\
\hline JS 20-69 & 4.36 & 2.89 & 33.61 & 0.89 \\
\hline JS 20-98 & 3.46 & 3 & 13.29 & 0.35 \\
\hline JS 97-52 & 5.33 & 4.98 & 6.62 & 0.18 \\
\hline DAVIS & 5.88 & 4.97 & 15.52 & 0.41 \\
\hline YOUNG & 9.25 & 2.38 & 74.28 & 1.98 \\
\hline JS 21-17 & 7.26 & 6.5 & 10.50 & 0.28 \\
\hline AMS MB-518 & 6.72 & 3.38 & 49.65 & 1.32 \\
\hline TGX 852-3D & 9.52 & 8.58 & 9.93 & 0.26 \\
\hline MACS-58 & 5.48 & 3.16 & 42.24 & 1.12 \\
\hline SKY/AK-403 & 3.16 & 1.79 & 43.47 & 1.16 \\
\hline HARDEE & 6.79 & 3.19 & 53.06 & 1.41 \\
\hline JS 21-73 & 4.58 & 4.36 & 4.87 & 0.13 \\
\hline CAT-142 & 3.88 & 2.7 & 30.47 & 0.81 \\
\hline CAT-649 & 4.07 & 3.24 & 20.35 & 0.54 \\
\hline CAT-703 & 3.14 & 2.47 & 21.31 & 0.57 \\
\hline CAT-3293 & 4.11 & 3.26 & 20.74 & 0.55 \\
\hline CAT-2082 & 7.13 & 6.5 & 8.83 & 0.24 \\
\hline AGS-38 & 2.65 & 1.50 & 43.27 & 1.15 \\
\hline AMS-59 & 1.33 & 0.81 & 38.74 & 1.03 \\
\hline AMS-19B & 1.37 & 0.8 & 41.60 & 1.11 \\
\hline AMS-26A & 3.68 & 2.7 & 26.69 & 0.71 \\
\hline AMS-148 & 6.14 & 2.83 & 53.90 & 1.43 \\
\hline SQL-8 & 8.39 & 2.31 & 72.43 & 1.93 \\
\hline SQL-31 & 6.7 & 2.44 & 63.53 & 1.69 \\
\hline SQL-88 & 4.13 & 3.18 & 23.06 & 0.61 \\
\hline SQL-89 & 8.57 & 3.63 & 57.63 & 1.53 \\
\hline SQL-106 & 2.28 & 1.80 & 21.13 & 0.56 \\
\hline JS 21-71 & 2.93 & 2.29 & 21.81 & 0.58 \\
\hline JS 21-72 & 10.63 & 2.64 & 75.14 & 2.00 \\
\hline
\end{tabular}




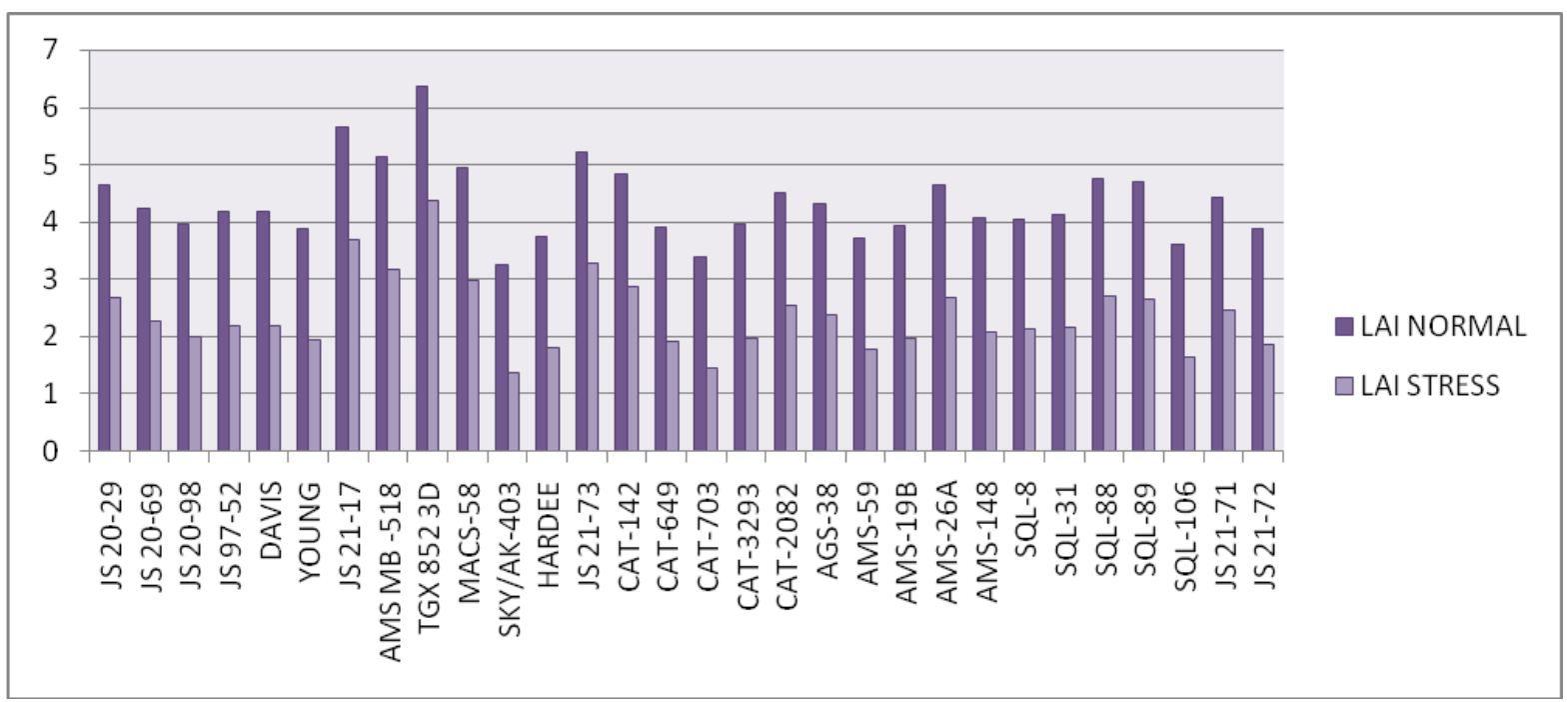

Fig.1 Effect of post anthesis drought stress on leaf area index

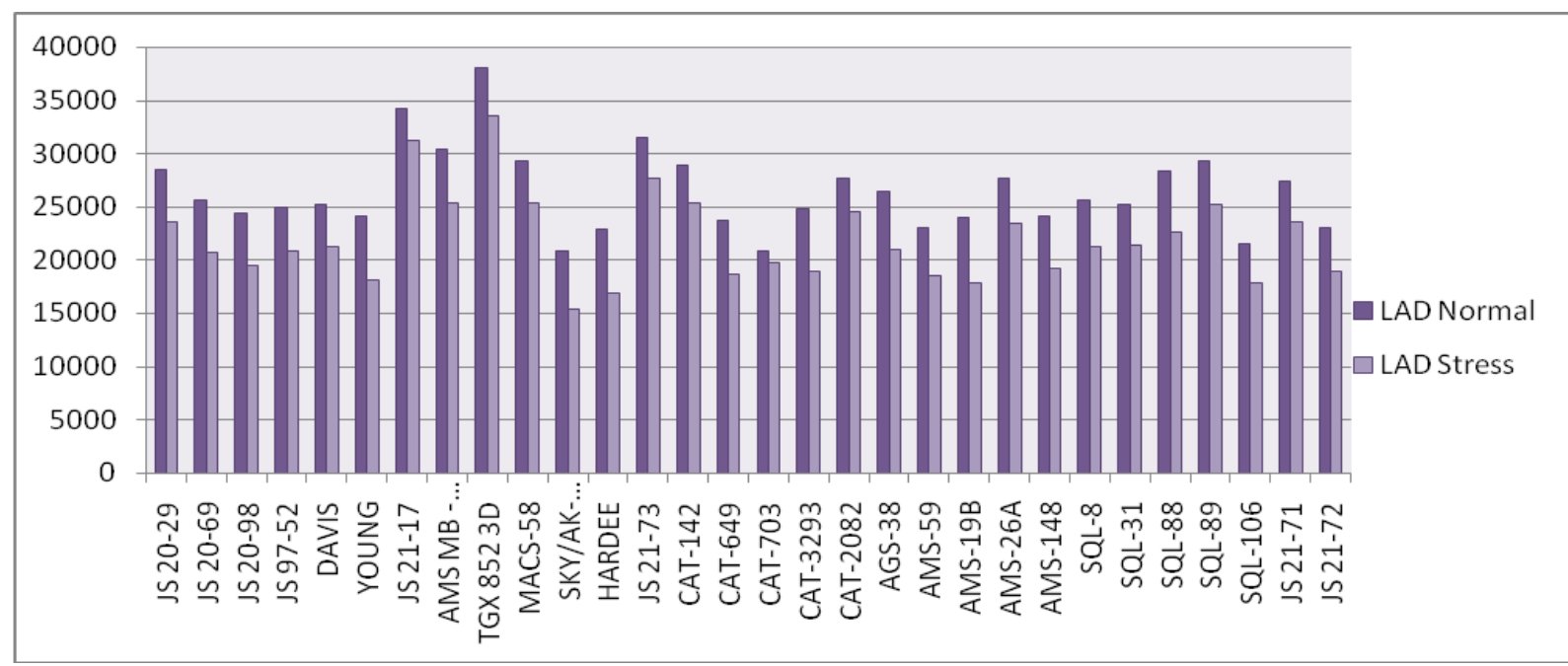

Fig.2 Effect of post anthesis drought stress on leaf area duration

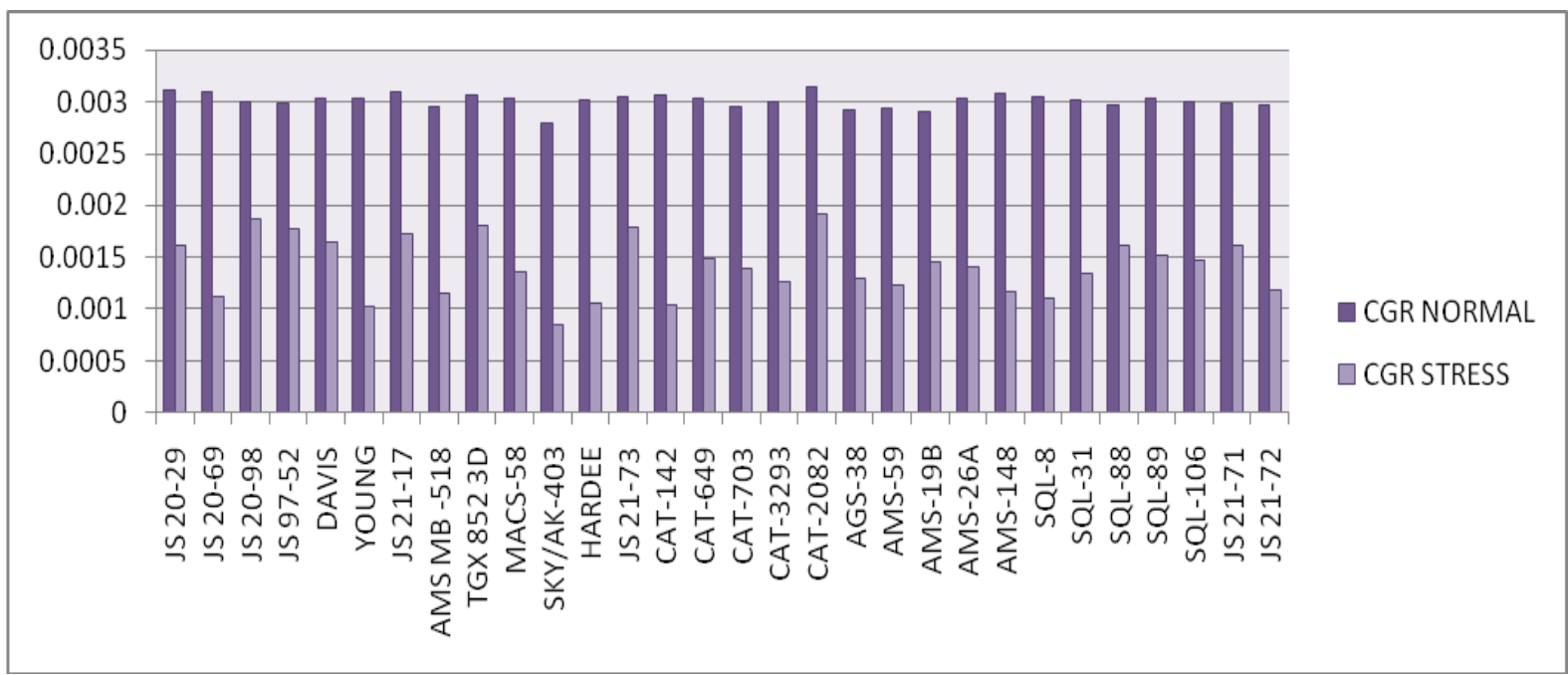

Fig.3 Effect of post anthesis drought stress on crop growth rate 


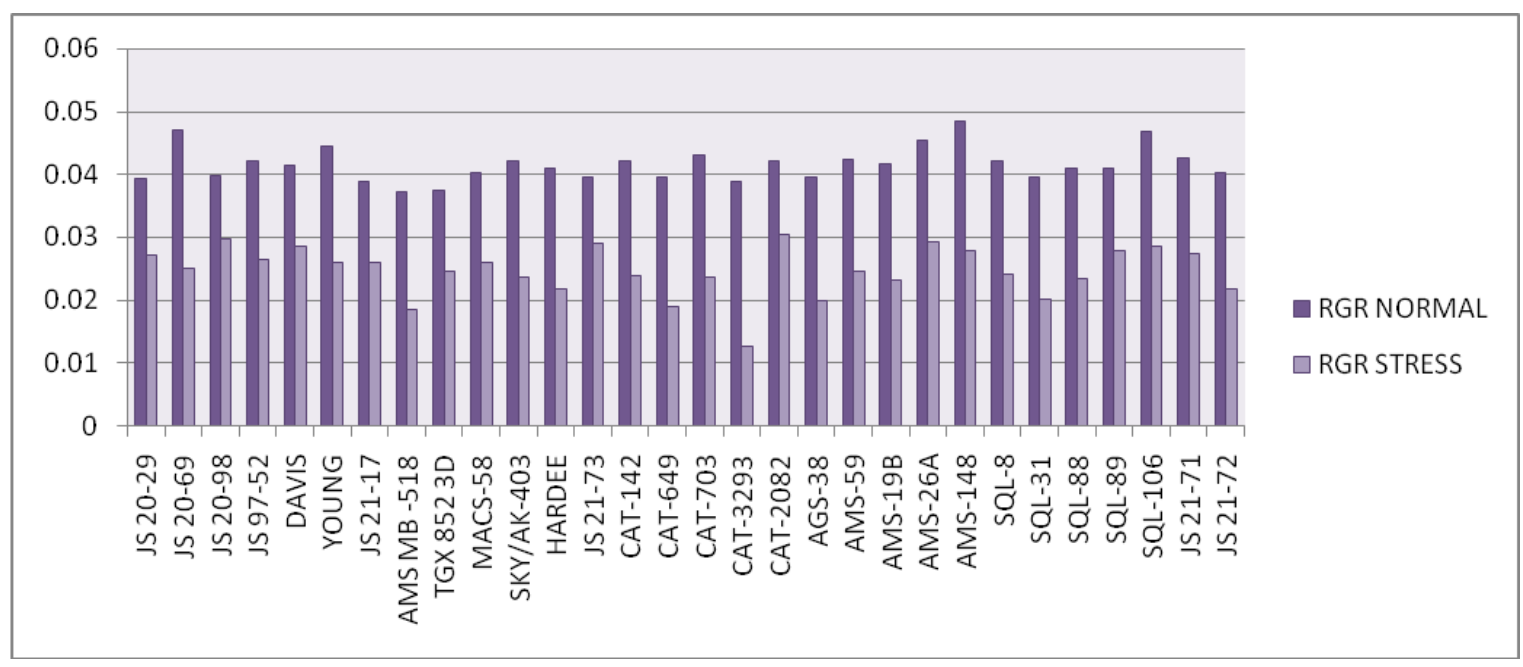

Fig.4 Effect of post anthesis drought stress on relative growth rate

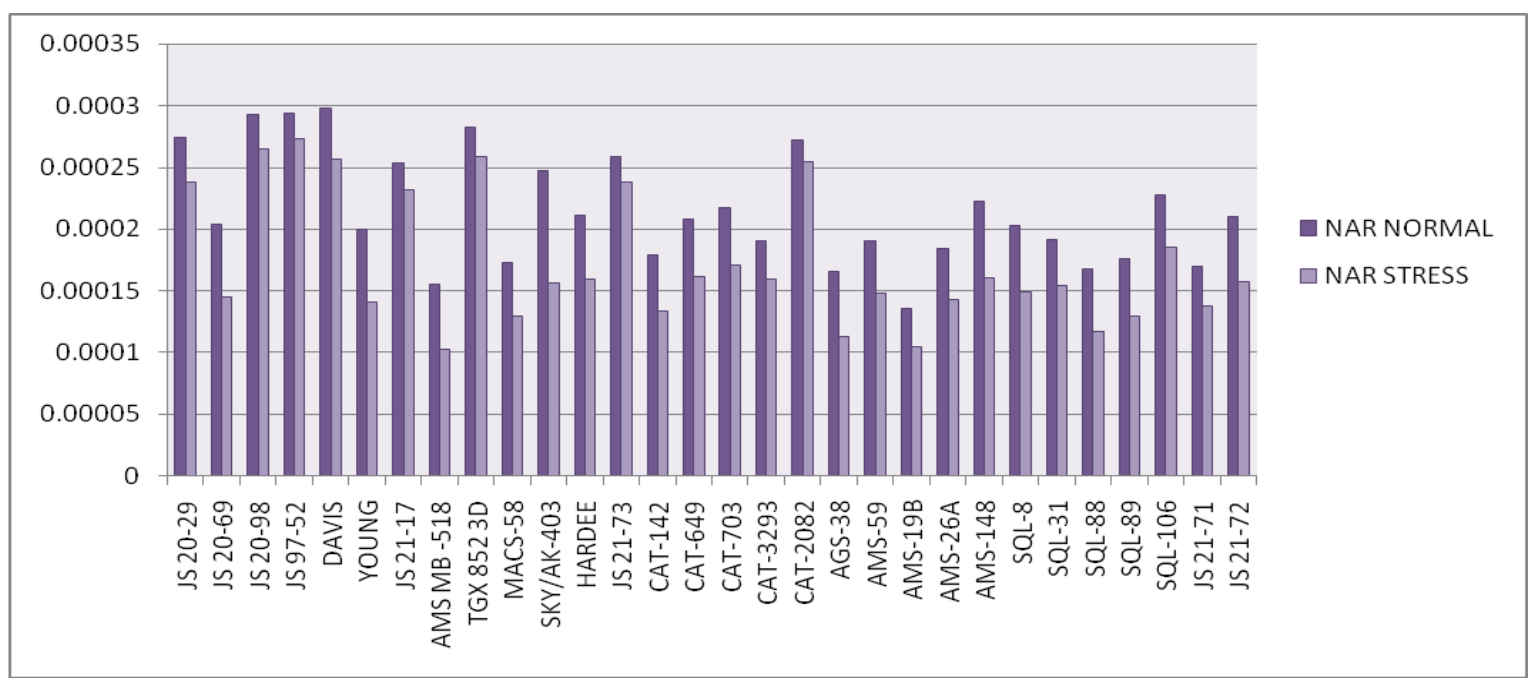

Fig.5 Effect of post anthesis drought stress on net assimilation rate

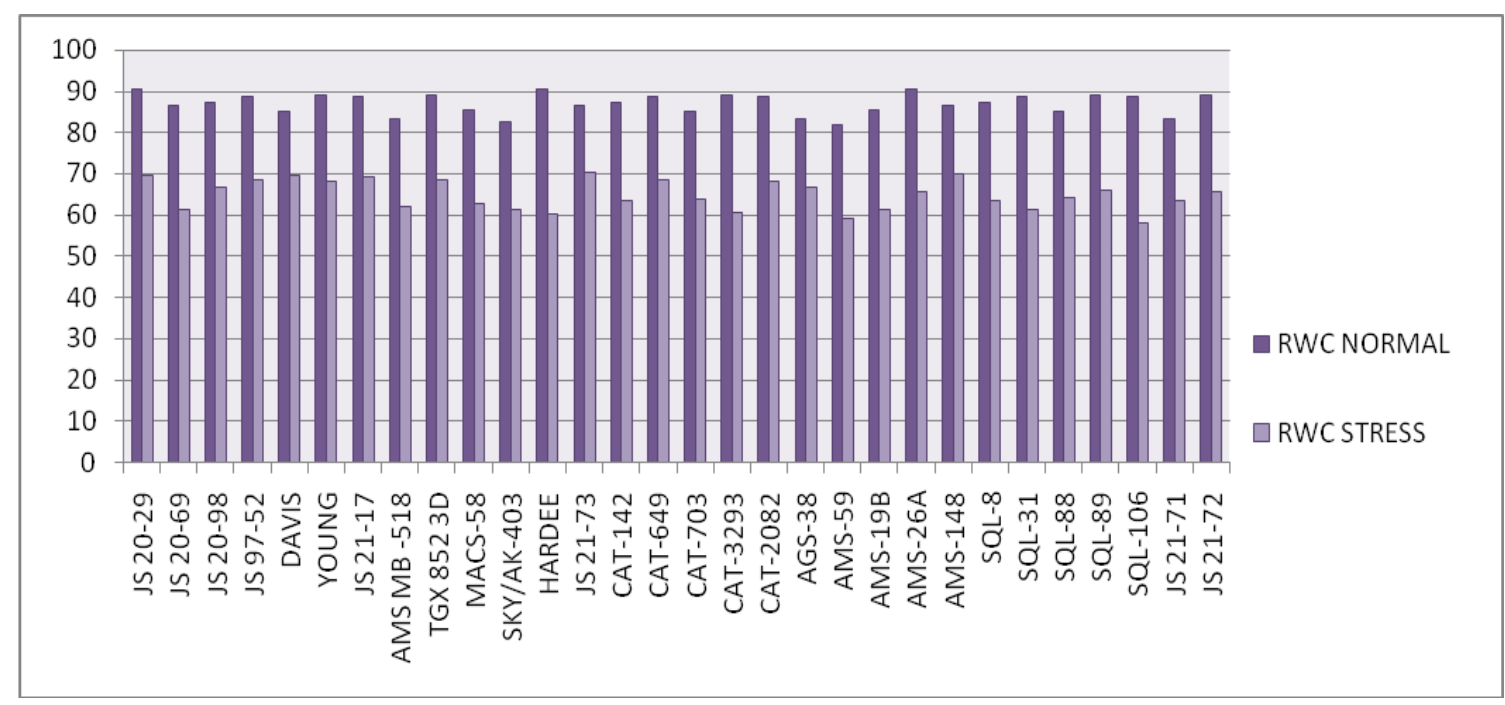

Fig.6 Effect of post anthesis drough stress on relative water content 


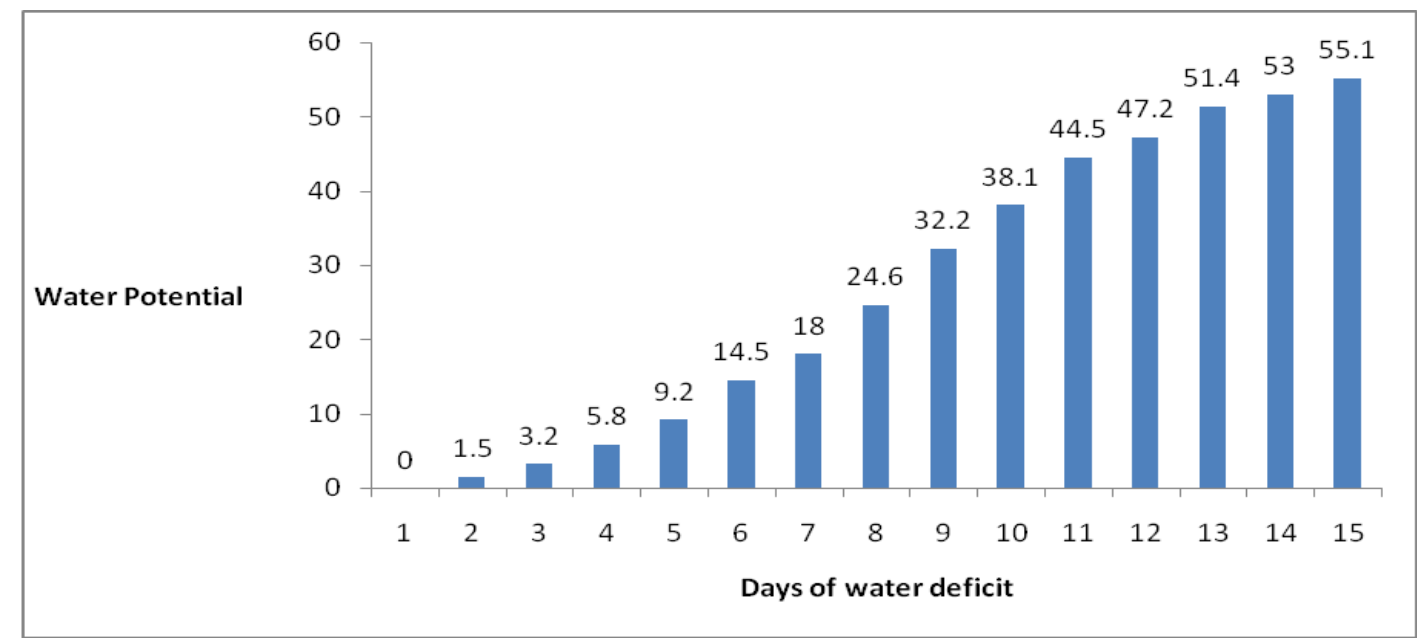

Fig.7 Monitoring of soil water potential with tensiometer

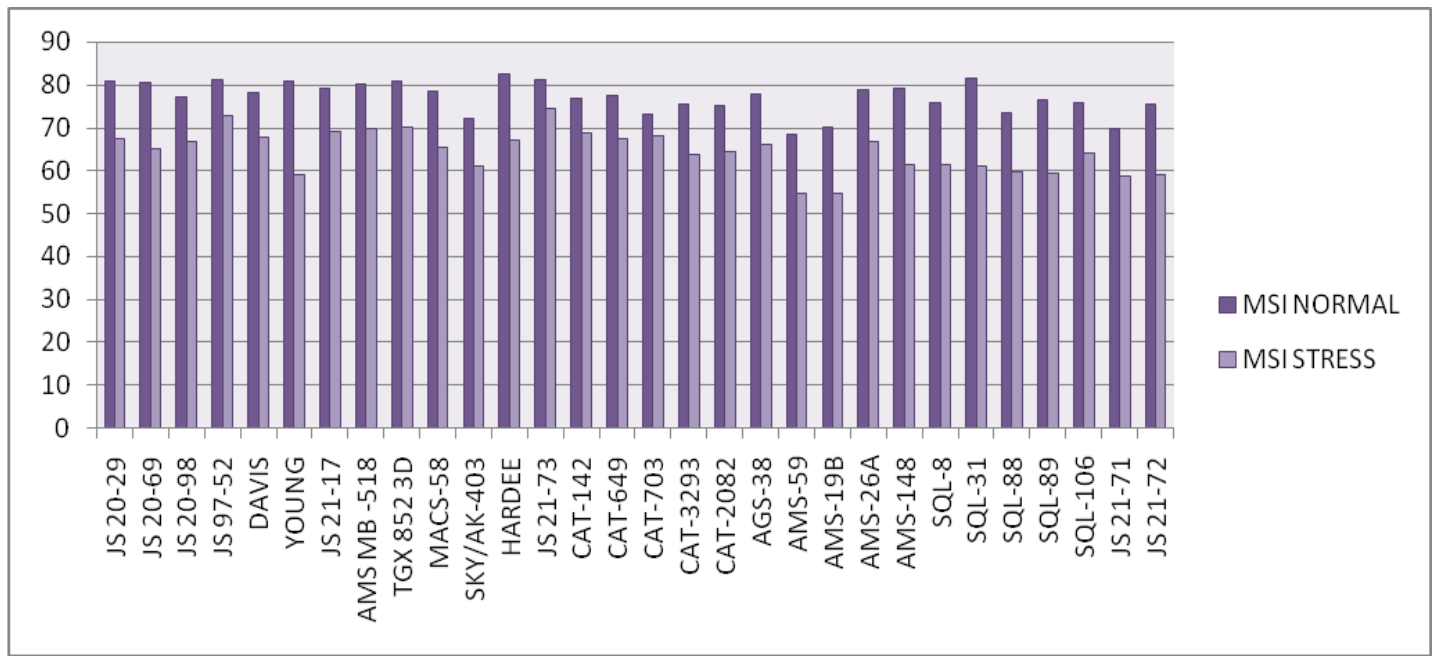

Fig.8 Effect of post anthesis drought stress on msi (\%)

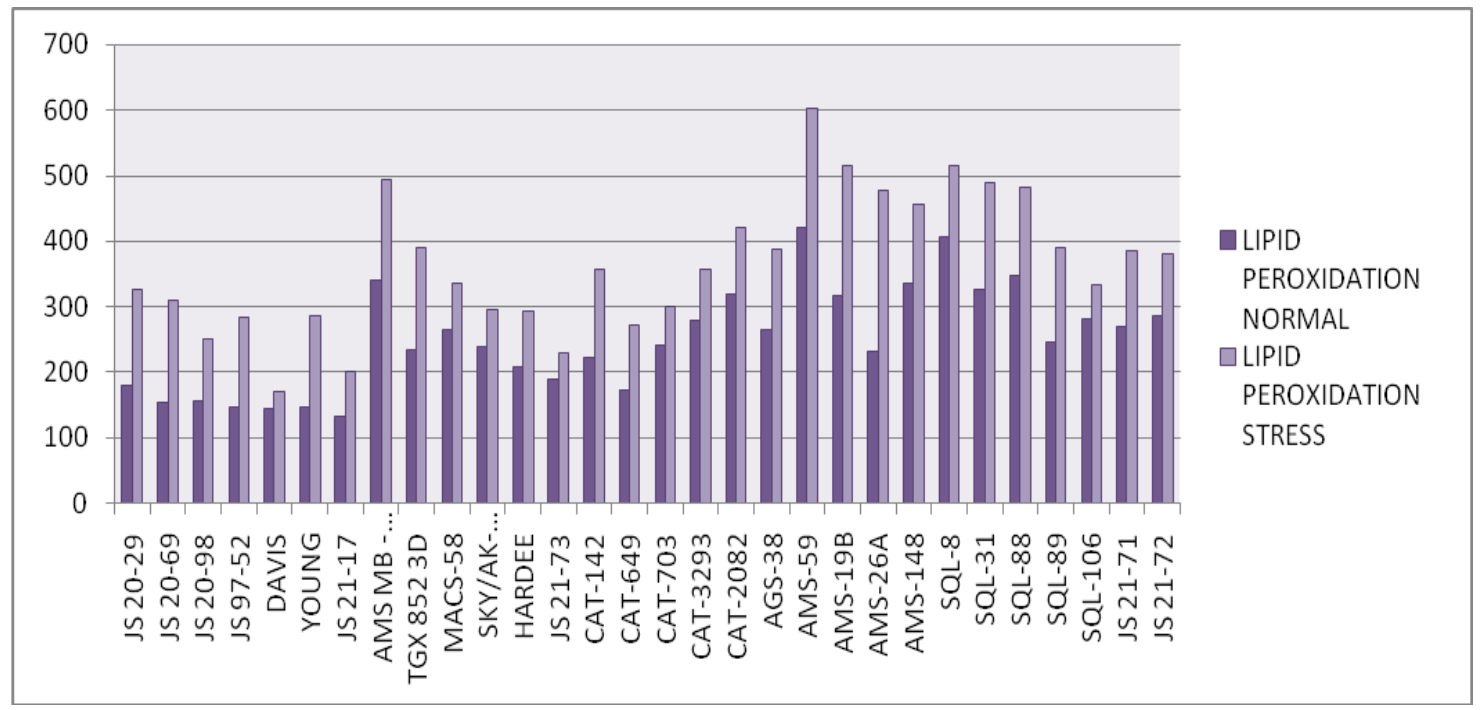

Fig.9 Effect of post anthesis drought stress on lipid peroxidation 


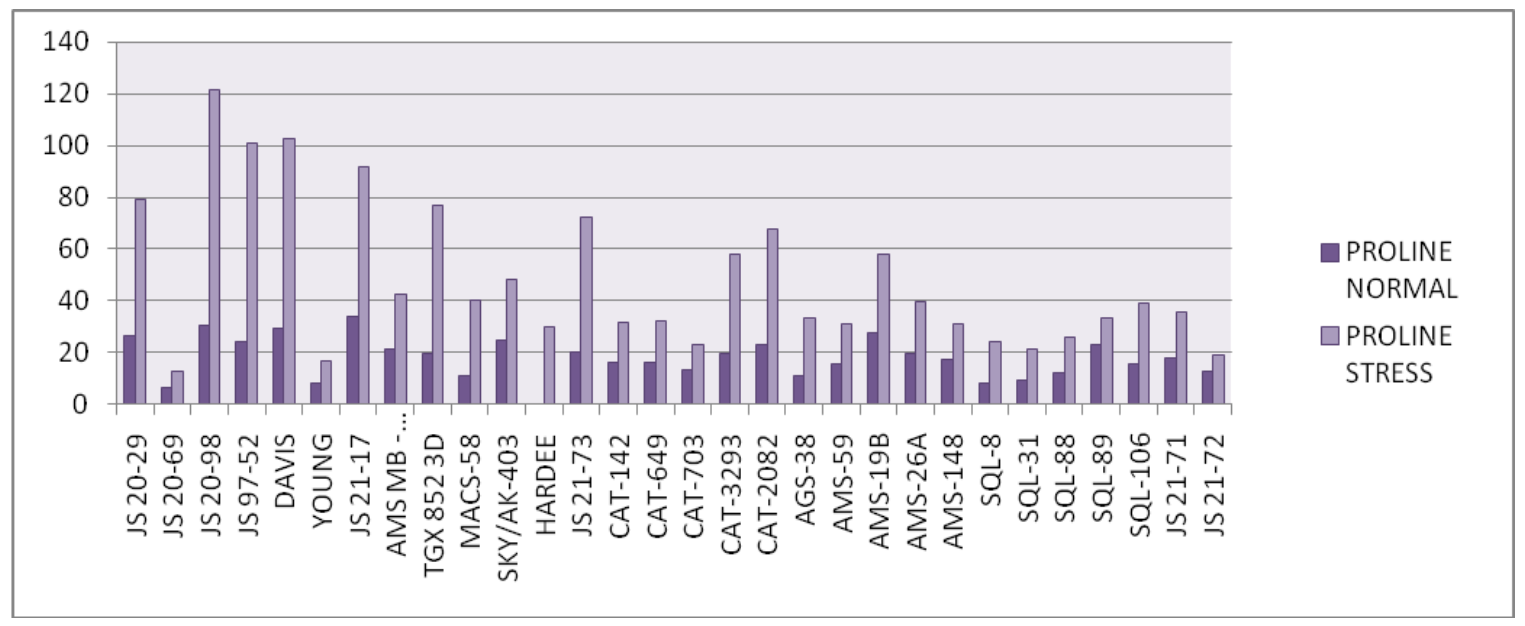

Fig.10 Effect of post anthesis drpught stress on proline content

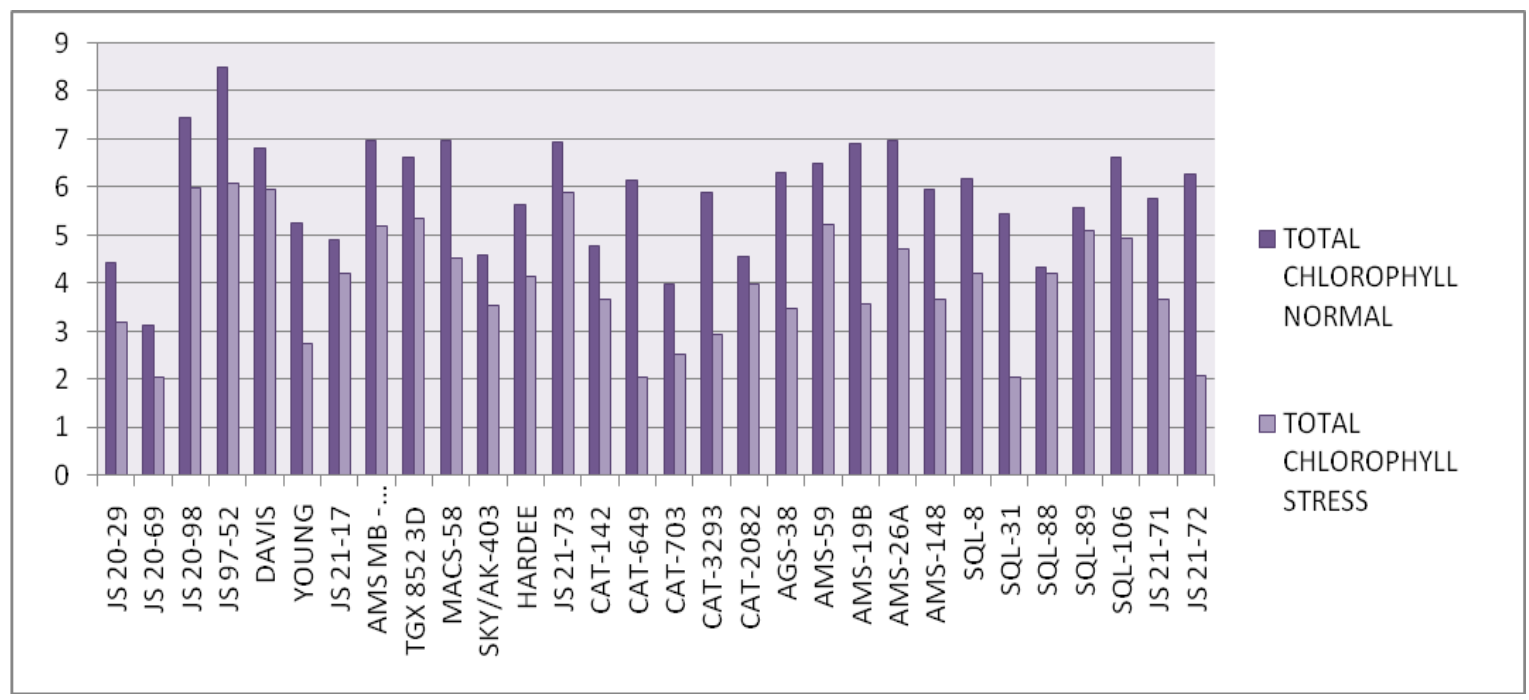

Fig.11 Effect of post anthesis drought stress on total chlorophyll content

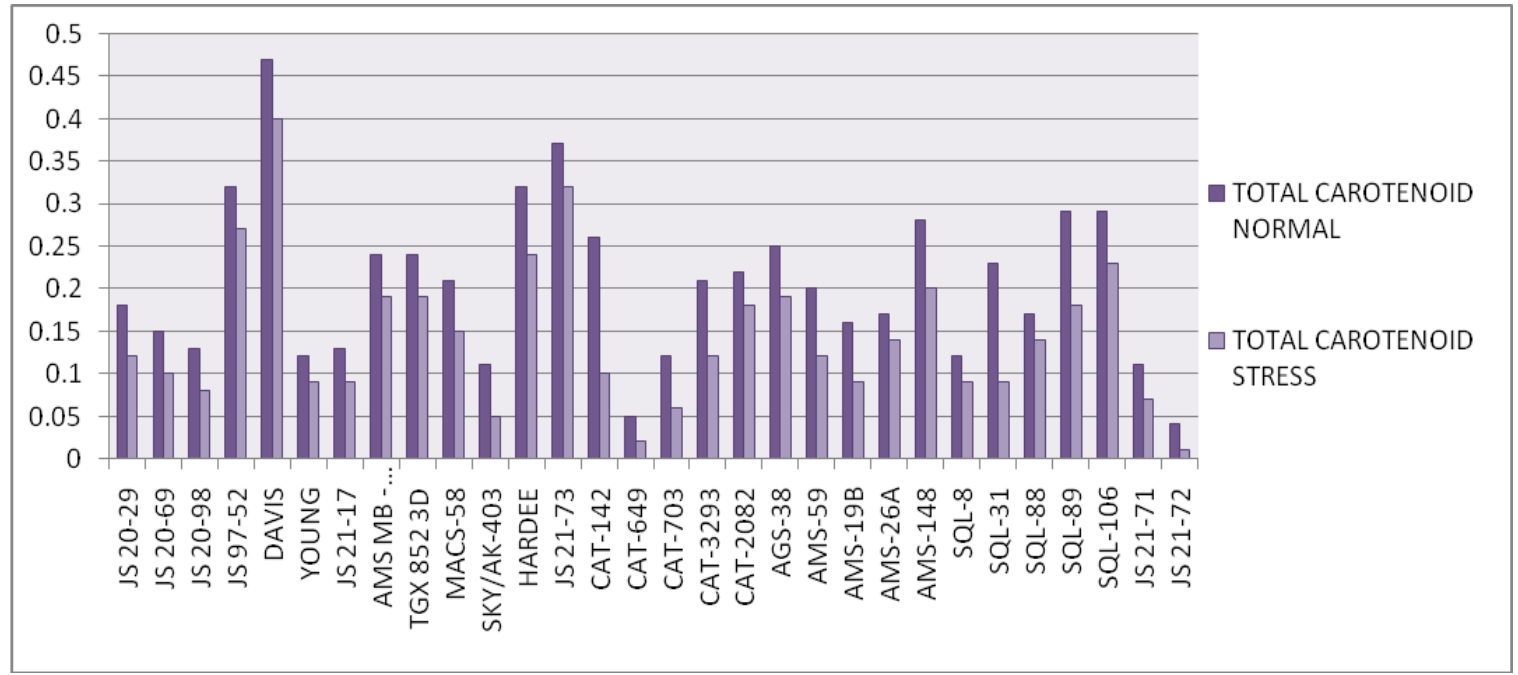

Fig.12 Effect of post anthesis drought stress on total carotenoid content 


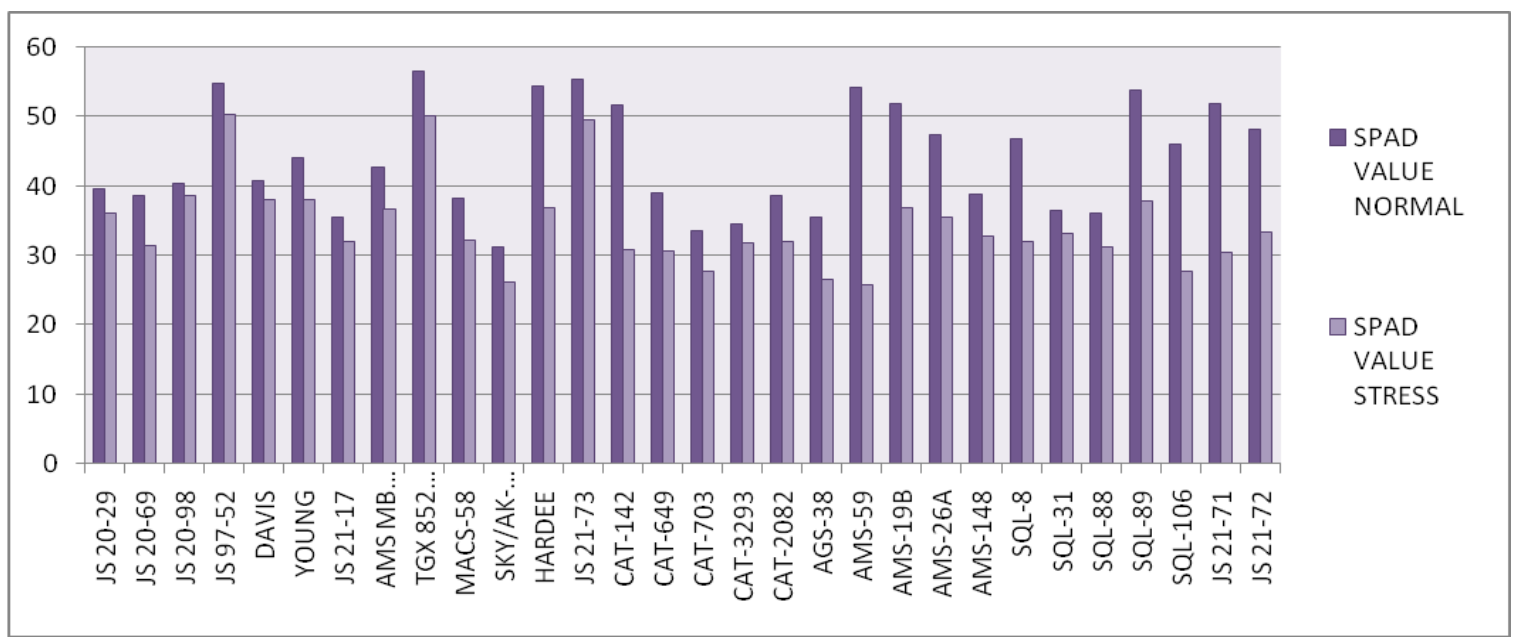

Fig.13 Effect of post anthesis drought stress on spad chlorophyll meter reading

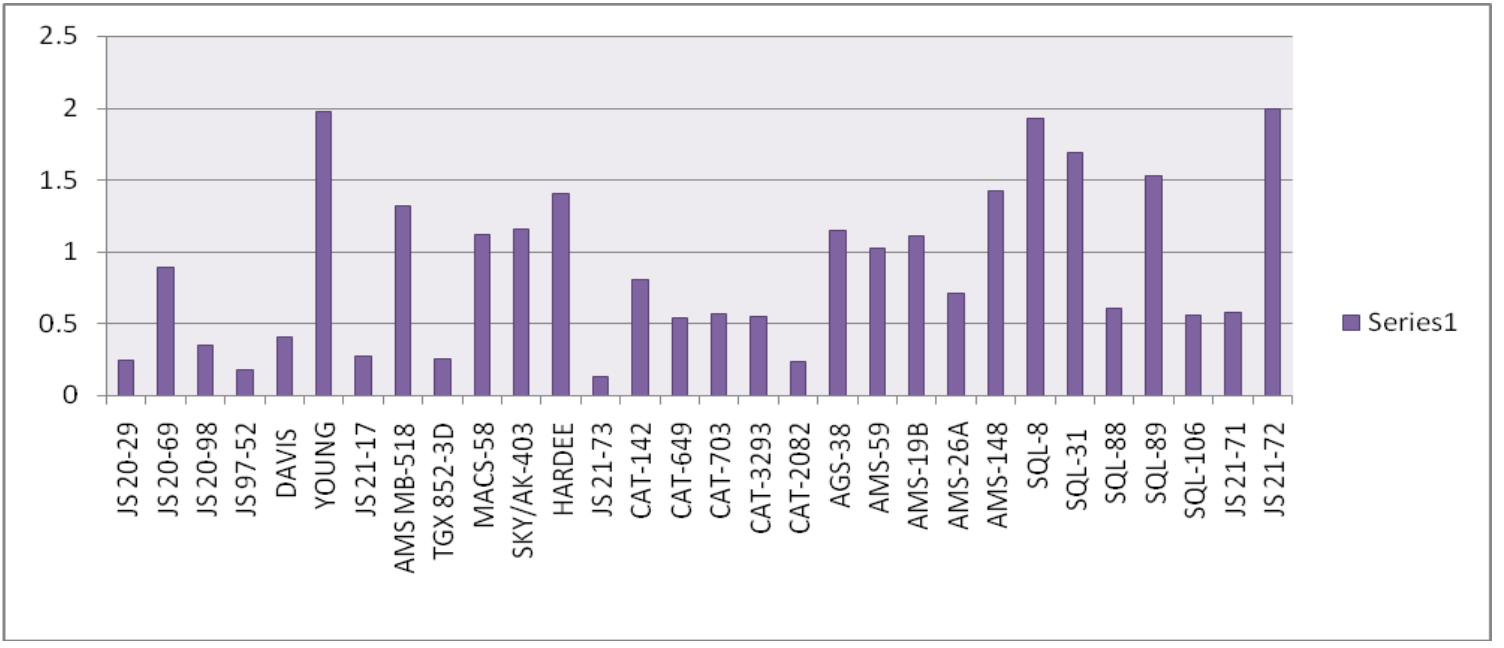

Fig.14 Effect of post anthesis drought stress on drought susceptibility index

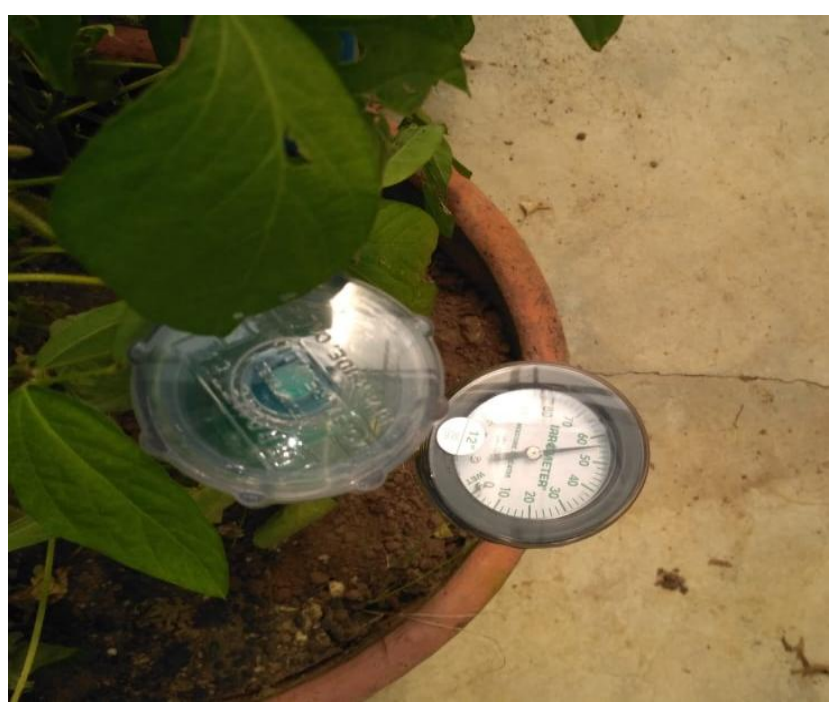

Fig.15 Tensiometric reading 


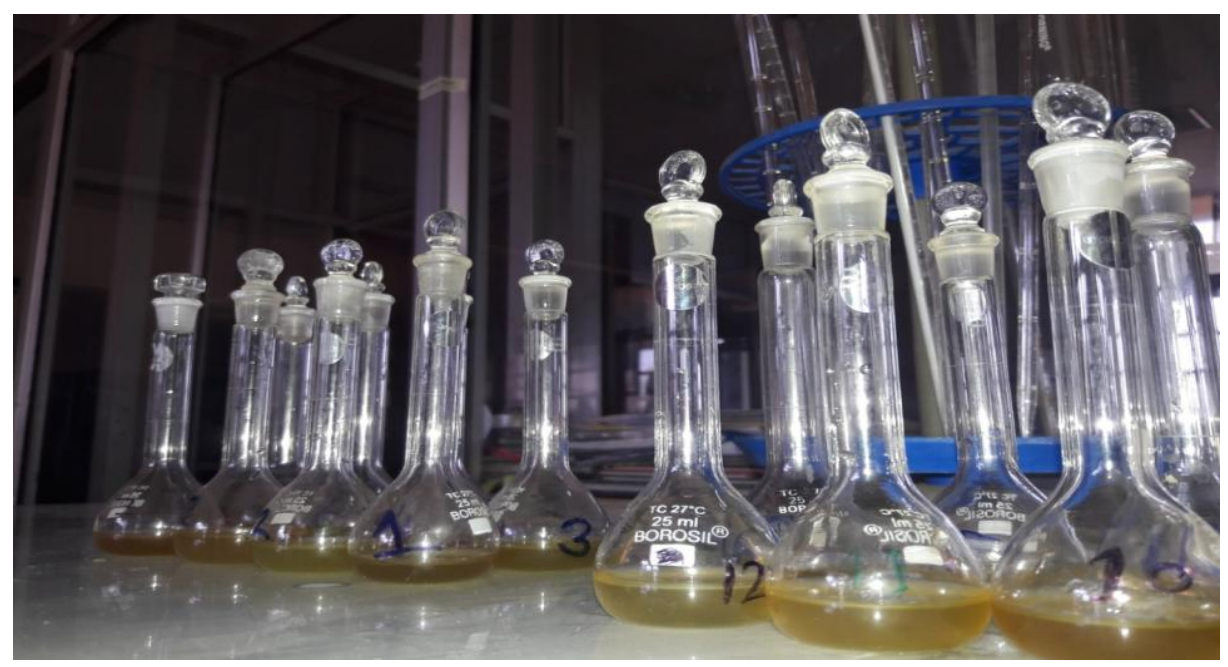

Fig.16 Estimation of Lipid peroxidation

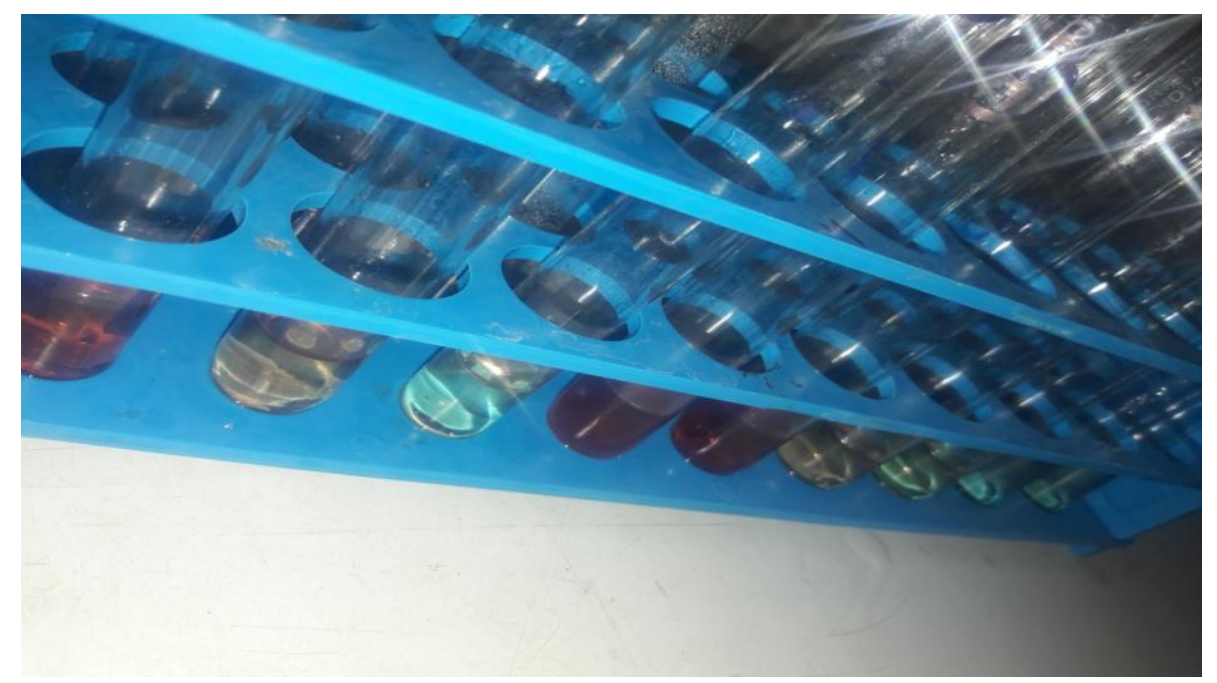

Fig.17 Estimation of proline content

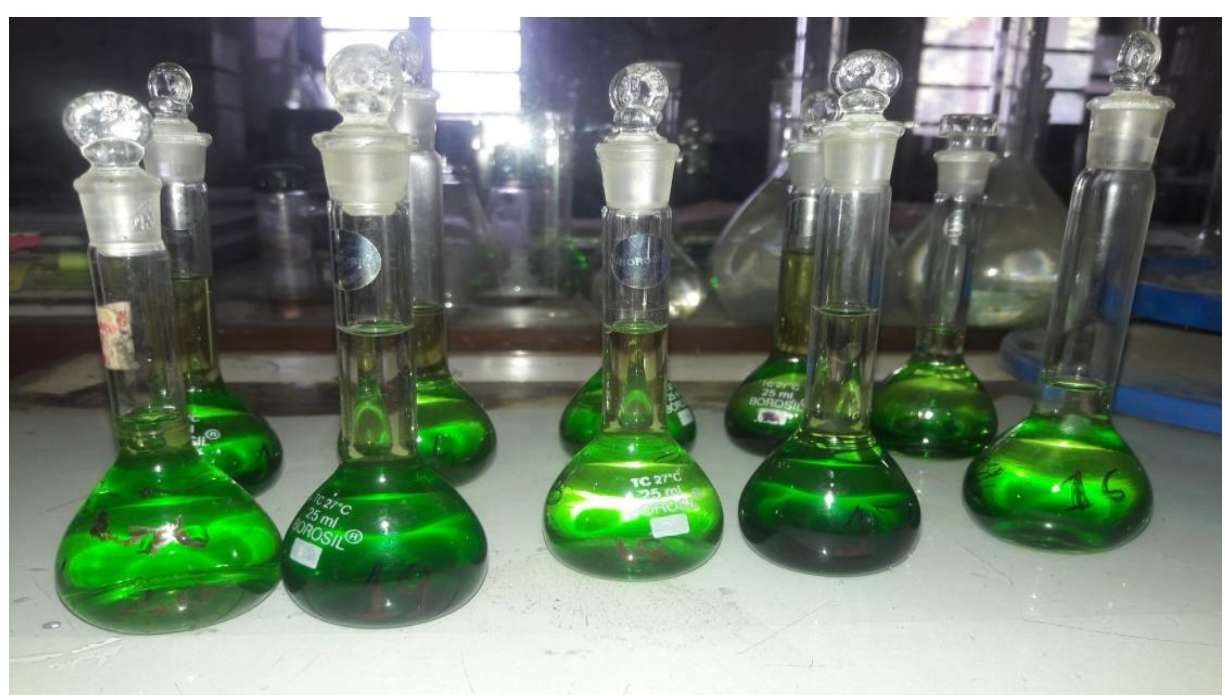

Fig.18 Chlorophyll and Carotenoid estimation 
Genotype JS 97-52 recorded lowest DSI value of 0.18 and genotype JS 21-72 recorded highest value of DSI i.e. 2.00 (Table no. 5, fig. no. 14). Ramakrishnan et al., (2016), Bhatia and Jumrani (2016).

On the basis of yield reduction percentage and drought susceptibility index (Table no. 6) genotypes which have been identified as drought tolerant are JS 20-29, JS 20-98, JS 97-52, JS 21-17, JS 21-73, DAVIS, TGX 8523D and CAT 2082.

\section{Acknowledgements}

The author is grateful to the glasshouse of botanical garden and laboratory of department of plant physiology, Jawaharal Nehru Agricultural University for providing all the research facilities.

\section{References}

Arnon DI. 1949. Copper enzyme polyphenoloxides in isolated chloroplast in vita vulgarish plant physiology. 24:115.

Babu N, Hittalmani S, Shivakumar N and Nandini C.2011. Effect of drought on yield potential and drought susceptibility index of promising aerobic rice (Oryza sativa L.) genotypes. Electronic Journal of Plant Breeding. 2(3):295- 302.

Bajji M, Kinet J and Lulls S. 2002. The use of the electrolyte leakage method for assessing cell membrane stability as a water stress tolerance test in durum wheat. Plant Growth Regulation. 36: 6170.

Barrs HE and Weatherley PE. 1962. A reexamination of the Relative Turgidity Technique for estimating water deficits in leaves. Australian Journal of Biological Sciences. 15(3): 413-428.

Bates LS, Waldren RP, Teare ID (1973) Rapid determination of free proline for waterstress studies. Plant Soil 39:205-207..

Bhatia VS and Jumrani K. 2016. A maximin- minimax approach for classifying soybean genotypes for drought tolerance based on yield potential and loss. Plant Breeding. 135(6): 691-700.

Bhatia VS, Jumrani K and Pandey GP. 2014. Developing drought tolerance in soybean using physiological approaches. Soybean Research 12(1): 1-19.

Bhatia VS, Jumrani K and Pandey GP. 2014. Evaluation of the usefulness of senescing agent potassium iodide (KI) as a screening tool for tolerance to terminal drought in soybean. Plant Knowledge Journal 3(1): 23-30.

Boyer JS. 1983. Environmental stress and crop yields. In CD Raper and P.J Kramer, eds, Crop reaction to water and temperature stresses in humid, temperate climates. Boulder, CO: Westview Press. Pp. 3-7.

Chowdhury JA , Karim MA, Khaliq QA and Ahmed AU.2017. Effect of drought stress on bio-chemical change and cell membrane stability of soybean genotypes. Bangladesh Journal Agril. Res. 42(3): 475-485.

Chowdhury JA , Karim MA, Khaliq QA and Ahmed AU.2017.Effect of drought stress on bio-chemical change and cell membrane stability of soybean genotypes. Bangladesh Journal Agril. Res. 42(3): 475-485.

Chowdhury JA, Karim MA, Khaliq QA, Solaiman RM and Ahmed JU. 2016. Screening of soybean (glycine $\max \mathrm{L}$.) genotypes underwater stress condition. Bangladesh Journal Agril. Res. 41(3): 441-450.

Director's report 2018-19. AICRP on soybean. ICAR-Indian Institute of soybean Research, Indore, M.P.

Eck HV, Mathers AC and Music JT. 1987. Plant water stress at various growth and yield of soybean. Field Crop Res. 17(1):116.

Farooq M, Wahid A, Kobayashi N, Fujita D and Basra SMA. 2009. Plant drought stress effects, mechanisms and management. Agron. Sustain. Dev. 29: 185-212.

Fischer RA and Maurer R. 1978. Drought 
resistance in spring wheat cultivars. I. Grain yield responses Australian Journal of Agricultural Research. 29(5): 897-912.

Gardner FP, Pearecer RB and Mitchell RL. 1985. Growth and Development. In Physiology and crop plants. The IOWA State Univ. Press: 187-208.

Ghorbanli M, Gafarabad M, Amirkian T and Mamaghani BA. 2012. Investigation of proline, total protein, chlorophyll, ascorbate and dehydro-ascorbate changes under drought stress in Akria and Mobil tomato cultivars. Irnian Journal of Plant Physiology 3: 651-658.

Golezani KG, Bakhshy J, Zehtab-Salmasi S, Moghaddam M. 2013. Changes in leaf characteristics and grain yield of soybean in response to shading and water stress. International Journal of Biosciences 3: 71-79.

Gomez and Gomez. 1984. Analysis of covariance in agronomy and crop research. Canadian Journal of Plant Science. 91(4):621-64.

Guler NS, Pehlivan N. 2016. Exogenous lowdose hydrogen peroxide enhances drought tolerance of soybean through inducing antioxidant system. Acta Biol Hung. 67(2):169-83.

Heath RL and Packer L. 1968. Photoperoxidation in isolated chloroplasts. I. Kinetics and stoichiometry of fatty acid peroxidation. Archives Biochemistry Biophysics. 125(1): 180198.

Hossain MM, Lam H and Zhang J.2015. Responses in gas exchange and water statusbetween drought-tolerant and susceptible soybean genotypes with ABA application. The crop journal.3:500-506.

Hossain MM, Liu X, Qi X, Lam HM and Zhan J. 2014. Differences between soybean genotypes in physiological response to sequential soil drying and rewetting. The crop Journal. 2: 366-380.

Kavi Kishor PB, Sangam S, Amrutha RN, Sri Laxmi P, Naidu KR, Rao KRSS, Rao S, Reddy P, Theriappan P, Sreenivasulu N (2005) Regulation of proline biosynthesis, degradation, uptake and transport in higher plants: Its implications in plant growth and abiotic stress tolerance. Curr Science 88: 424-438.

Khaleghi E, Arzani K, Moallemi N and Barzegar M. 2012. Evaluation of chlorophyll content and chlorophyll fluorescence parameters and relationships between chlorophyll $\mathrm{a}, \mathrm{b}$ and chlorophyll content index under water stress in Olea europaea cv. Dezful. World Acad. Sci. Eng. Technol. 68: 1154-1157.

Kirk JTO, and Allen RL. 1965. Dependence of chloroplast pigments synthesis on protein synthetic effects on actilione. Biochem. Biophysics Res. JournaLCanada.27: 523530.

Leith H. 1975. Measurement of calorific values. In. H. Leith and R. Whittaker (eds.). Primary Productivity of the Biosphere. Berlin: Springer-Verlag: 119-129.

Li P, Wu PT, and Chen JL. 2012a. Evaluation of flag leaf chlorophyll content index in 30 spring wheat genotypes under three irrigation regimes. Australian Journal of Crop Science 6: 1123-1130.

Lobato AKS, Oliveira Neto CF, Costa RCL, Santos Filho BG, Cost RCL, Cruz FJR, Neves HKB, Lopes MJS (2008) Physiological and biochemical behavior in soybean (Glycine max cv. Sambabia) plants under water deficit. Aust J. Crop Sci 2: 25-23.

Mac Kinney G. 1941. Absorption of light by chlorophyll solutions. J Biol Chem. 140: 513-531.

Mall AK, Swain P, Das S, Singh ON and Kumar A. 2011. Effect of Drought on Yield and Drought Susceptibility Index for Quality Characters of Promising Rice Genotypes Cereal Res. Comm. 39(1): 2231.

Manavalan LP, Guttikonda SK, Tran LS and Nguyen HT. 2009. Physiological and molecular approaches to improve drought resistance in soybean. Plant Cell Physiology 50: 1260-1276.

Mottaghian A, Pirdashti H and Bahmanyar MA. 2010. Dry matter accumulation and 
physiological indices of two soybean cultivars in response to enriched sewage sludge compost. World Applied Sciences Journal. 8(5): 578-588.

Pandey RK, Herrera WAT, Villegas $\mathrm{N}$ and Pendleton JW. 1984. Drought response of grain legumes under irrigation gradient: iii. Plant growth. Agronomy Journal Abstract. 76(4): 557-560.

Panse V G and Sukhatme P V.1985.Statistical Methods for Agricultural workers ( $2^{\text {nd }}$ edition).Indian Council of Agricultural Research, New Delhi,381 pg.

Park JH, Jin YM and Kim KS. 1998. Physiological effects of water stress at different growth stages on metabolites in soybean leaves. J. Agro.Environ. Sci., 40(1):7-13.

Rahbarian R, Nejad RK, Ganjeali A, Baghel A, Najafi F. 2011. Drought stress effects on photosynthesis, chlorophyll fluorescence and water relations in tolerant and susceptible chickpea (cicer genotypes L.) genotypes .Acta biology Cracov. Bot. 53, 47-56.

Ramakrishnan RS, Ghodke PH, Nagar S, Vinod R, Singh BP and Arrora A. 2016. Genetic analysis of stay green trait and its association with morpho physiological trait under water deficit stress in wheat. Journal Indian journal of plant genetic resource. 29(2):177-183.

Ramakrishnan RS, Ghodke PH, Nagar S, Vinod R, Singh BP and Arrora A. 2016. Genetic analysis of stay green trait and its association with morpho physiological trait under water deficit stress in wheat. Journal Indian journal of plant genetic resource. 29(2):177-183

Rampino P, Mita G, Fasano P, Borrelli GM, Aprile A, Dalessandro G, De-Bellis L and Perrotta C. 2012. Novel durum wheat genes up-regulated in response to a combination of heat and drought stress. Plant Physiology and Biochemistry 56:72-78

Sairam RK. 1994. Effect of moisture stress on physiological activities of two contrasting wheat genotypes. 32: 593-594.

Seki, M., T. Umezawa, K. Urano, and K. Shinozaki. 2007. Regulatory metabolic networks in drought stress responses. Curr. Opin. Plant Biol. 10: 296-302.

SOPA. 2018. The Soybean Processors Association of India email: sopa@sopa.org.

Souza PI, Egli DB, Bruening WP and De Souza PI. 1997. Water stress during seed filling and leaf senescence in soybean. Agron. J. 89 (5): 807-812.

Wang P, Isoda A. and Wei G. 1995. Growth and adaptation of soybean cultivars under water stress conditions III. Yield response and dry matter production. Jpn. J. Crop Sci. 64: 777-783.

Watson DJ. 1952. Physiological basis of varieties in yield. Advance in Agronomy. 4: 101-145.

Williams RF. 1946. The Physiology of Plant Growth with Special Reference to the Concept of Net Assimilation Rate. Annals of Botany. 10(37): 41-72.

Zhang, X., E.H. Ervin, G.K. Evanylo and K.C. Haering. 2009. Impact of biosolids on hormone metabolism in drought-stressed tall fescue. Crop Sci. 49:1893-1901.

\section{How to cite this article:}

Swati Saraswat, Stuti Sharma, Ajay Meena and Shiv Ramakrishna, R. 2020. Physiological and Biochemical Responses of Soybean to Post Anthesis Drought Stress. Int.J.Curr.Microbiol.App.Sci. 9(05): 3070-3092. doi: https://doi.org/10.20546/ijcmas.2020.905.365 